\title{
APLIKASI THEORY OF PLANNED BEHAVIOR UNTUK MEMPREDIKSI PERILAKU MAHASISWA MEMBELI LAPTOP LENOVO (Studi Kasus: Mahasiswa FE- Unika Santo Thomas SU)
}

\author{
Darwis Tamba \\ Universitas Katolik Santo Thomas Medan Jl. Setia Budi No. 479F, 20132, Indonesia \\ e-mail: $\underline{\text { darwistamba1141@gmail.com }}$
}

\begin{abstract}
The purpose of this study to analyze the application of theory of planned behavior to predict student behavior to buy Lenovo laptops. Benefits This study provides input to other researchers in conducting further research on the same topic and add insight and knowledge of researchers in the field of consumer behavior, especially about the application of theory of planned behavior to predict student behavior to buy a laptop lenovo.Total sample 96 respondents, data collection method through questioner and documentation, Descriptive analysis technique. The results showed based on the observed variables that: Attitudes, subjective norms and control behaviors felt by students FE Unika St. Thomas SU on average gives a positive influence on the behavior to buy branded Lenovo laptops. This is in line with the behavioral interest equation $=B I=0.44 A b+0.16 S N+0.40 P C$. That is, the behavior of FE Unika St. Thomas SU to buy larger brand Lenovo laptops is influenced by attitudes of $0.44(44 \%)$ than perceived behavioral controls of $0.40(40 \%$ and subjective norms $0.16(16 \%))$. attributes that students place to win competition and preferably, laptop manufacturers increase the influence of subjective norms and perceived behavioral control by offering various benefits to consumers.
\end{abstract}

Keywords: Attitude, subjective norm, Control perceived behavior, Interest and Behavior

\section{PENDAHULUAN}

Pada saat ini keadaan persaingan antar produsen semakin kompetitif yang ditandai dengan semakin banyaknya perusahaan yang menawarkan produk sejenis. Untuk memenangkan persaingan, perusahaan perlu mengetahui perilaku konsumen sebagai dasar penentuan strategi pemasaran. Dengan mengetahui perilaku konsumen, perusahaan dapat mengetahui keinginan dan kebutuhan konsumen, kemudian menciptakan alat pemuas kebutuhan dan menyampaikannya ke pasar melalui kegiatan pemasaran.

Perilaku konsumen merupakan tindakan langsung dalam mendapatkan, mengkonsumsi, serta menghabiskan produk dan jasa, termasuk proses keputusan yang mendahului dan mengikuti tindakan tersebut. Perilaku konsumen perlu dianalisis, karena tidak dapat dikendalikan langsung oleh perusahaan. Informasi perilaku konsumen diperoleh dari tenaga pemasar, dan hasil survei pasar.

Konsumen menginginkan produk yang memiliki karakteristik lebih cepat, murah dan lebih baik. Karakteristik lebih cepat berkaitan dengan dimensi waktu yang menggambarkan kecepatan dan kemudahan yang didapatkan dari produk. Karakteristik lebih murah berkaitan dengan harga produk. Karakteristik lebih baik berkaitan dengan dimensi kualitas produk. Dalam hal ini, kebanyakan produsen memberikan garansi sebagai jaminan atas kualitas produk yang ditawarkan.

Salah satu produk yang mempengaruhi perilaku konsumen saat ini adalah laptop, karena mampu memberi kemudahan dalam mengerjakan berbagai tugas-tugas, bentuknya kecil dan ringan, sehingga mudah dibawa kemana-mana. Setiap pembelian laptop dilengkapi dengan modem dan network connection untuk memudahkan pengguna untuk mengakses informasi dari internet. Tersedianya layanan hotspot mulai berkembang di berbagai tempat menjadi faktor pendorong makin populernya laptop. Hotspot merupakan lokasi dimana user dapat mengakses internet melalui mobile computer seperti laptop dan handphone yang 
mempunyai fasilitas Wifi tanpa menggunakan pulsa. Hotspot banyak ditemukan di kampus, perkantoran, kafe, toko buku, hotel, restoran dan lain sebagainya.

Gaya hidup digital telah menjadi bagian dari hidup manusia di dunia dan kepraktisan merupakan ciri utama dari perkembangan teknologi digital. Laptop dianggap sebagai salah satu hasil dari perkembangan teknologi yang sesuai dengan kebutuhan masyarakat yang memiliki mobilitas tinggi. Laptop mewakili gaya hidup manusia yang semakin fleksibel dan ingin segala sesuatunya menjadi lebih simple dan serba praktis, karena didukung dari segi desain dan ukurannya.

Teori perilaku terencana awalnya dinamai theory of reasoned action (teori tindakan beralasan), dikembangkan tahun 1967, selanjutnya teori tersebut terus direvisi dan diperluas oleh Icek Ajzen dan Martin Fishbein. Pada tahun 1980, theory of reasoned action digunakan untuk mempelajari perilaku manusia. Theory of reasoned action (teori tindakan beralasan) berhasil ketika diaplikasikan pada perilaku yang di bawah kendali individu sendiri. Jika perilaku tersebut tidak sepenuhnya di bawah kendali atau kemauan individu, meskipun ia sangat termotivasi oleh sikap dan norma subjektifnya, ia mungkin tidak akan secara nyata menampilkan perilaku tertentu. Untuk mengatasi kekurangan teori tindakan beralasan yang ditemukan oleh Ajzen dan Fishbein, maka pada tahun 1988 theory of planned behavior dikembangkan untuk memprediksi perilaku yang sepenuhnya tidak di bawah kendali individu.

Teori perilaku terencana (theory of planned behavior) didasarkan pada asumsi bahwa manusia adalah makhluk yang rasional dan menggunakan informasi yang mungkin baginya, secara sistematis. Orang memikirkan implikasi dari tindakan mereka sebelum mereka memutuskan untuk melakukan atau tidak melakukan perilaku tertentu. Teori perilaku terencana (theory of planned behavior) adalah teori yang menganalisis sikap konsumen, norma subjektif, dan kontrol perilaku yang dirasakan konsumen. Sikap konsumen mengukur cara seseorang merasakan suatu objek sebagai sesuatu hal yang positif atau negatif, serta menguntungkan atau merugikan. Sikap konsumen diharapkan dapat menentukan apa yang akan dilakukan di masa yang akan datang terhadap produk komputer merek tertentu (Lenovo), berarti konsumen itu mau menerima atau merasa senang terhadap produk komputer, sehingga bila produk komputer tersebut ditawarkan kepada konsumen, kemungkinan besar akan dibeli oleh konsumen tersebut.

Perilaku konsumen dalam membeli produk komputer tidak hanya dipengaruhi oleh sikap seseorang, tetapi juga dipengaruhi oleh variabel norma subyektif, karena produk komputer merupakan produk yang mempunyai keterlibatan tinggi dalam proses pengambilan keputusan beli. Jadi konsumen dalam hal ini perlu: mencari informasi, mengevaluasi alternatif, memilih salah satu alternatif, kemudian membeli. Untuk mengenal kebutuhan dan keinginan konsumen pada pasar sasaran untuk produk komputer, perlu dilakukan penelitian mengenai perilaku konsumen.

Kontrol perilaku yang dirasakan merupakan kondisi dimana orang percaya bahwa suatu tindakan mudah atau sulit dilakukan, karena mencakup pengalaman masa lalu yang dipertimbangkan seseorang. Dalam hal ini, tenaga pemasar harus mampu memahami konsumennya dengan mempelajari kebiasaan-kebiasaanya sehari-hari.

Roni (2009), meneliti theory of planned behavior untuk melakukan pembelian laptop oleh komunitas mahasiswa di Makassar. Theory of planned behavior merupakan pengembangan lebih lanjut theory of reasoned action dengan menambah variabel perceived behavioral control bahwa perilaku individu dibatasi oleh kekurangan atau keterbatasan dari sumber daya yang digunakan untuk melakukan perilaku. Teori ini mengenal kemungkinan bahwa banyak perilaku tidak semuanya di bawah kontrol penuh dari individu. Dari hasil penelitiannya menyimpulkan bahwa perilaku komunitas mahasiswa di Makassar lebih besar dipengaruhi oleh norma subjektif dari pada sikap dan kontrol perilaku. 
Bursan (2010), meneliti implementation of planned bahavior theory at the fakulty of economics student attitudes in buying laptop dengan fenomena adalah persaingan antar produsen yang menawarkan laptop semakin kompetitif sesuai perkembangan teknologi informasi, sehingga seseorang berperilaku tidak hanya dipengaruhi oleh sikap, norma subjektif, tetapi juga dipengaruhi oleh kontrol perilaku. Hasil penelitiannya menyimpulkan bahwa theory of planned behavior (sikap mahasiswa, norma subjektif dan kontrol perilaku) dapat digunakan untuk memprediksi perilaku mahasiswa untuk membeli laptop. Dari ketiga variabel tersebut yang paling berpengaruh terhadap perilaku mahasiswa untuk membeli laptop adalah sikap.

Fakultas Ekonomi Unika St. Thomas Sumatera Utara menyediakan hotspot (WIFI) yang dapat dimanfaatkan mahasiswa untuk mengakses internet untuk mengambil berbagai data dan informasi yang dibutuhkan secara gratis. Lenovo merupakan salah satu laptop yang banyak diminati mahasiswa untuk mempermudah pengerjaan tugas-tugasnya. Keadaan persaingan yang semakin kompetitif menyulitkan produsen laptop Lenovo untuk mempertahankan posisi pangsa pasarnya, dengan pesaing utama adalah Acer, Toshiba, Asus, Compaq, Dell, dan HP, karena perilaku konsumen tidak hanya dipengaruhi oleh sikap, norma subjektif, tetapi juga dipengaruhi oleh kontrol perilaku. Berdasarkan uraian tersebut di atas, penulis tertarik melakukan penelitian dengan judul : Penerapan theory of planned behavior untuk memprediksi perilaku mahasiswa untuk membeli laptop Lenovo (Studi kasus: Mahasiswa Fakultas Ekonomi Unika St. Thomas Sumatera Utara).

Berdasarkan identifikasi masalah, dapat dirumuskan masalah penelitian sebagai berikut: "Bagaimana penerapan theory of planned behavior untuk memprediksi perilaku mahasiswa untuk membeli laptop Lenovo (Studi kasus: Mahasiswa Fakultas Ekonomi Unika St. Thomas Sumatera Utara) ?".

\section{TINJAUAN PUSTAKA}

\section{A. Pengertian Pemasaran}

Konsep pemasaran merupakan suatu upaya perusahaan dalam memasarkan produknya sehingga sampai ke tangan konsumen. Pemasaran memfokuskan diri pada titik pasar sasaran dan pada kebutuhan pelanggan dan sarana yang digunakan untuk mencapai tujuan melalui pemasaran yang terintegrasi dan perusahaan mendapat laba dari kepuasan pelanggan. Perusahaan harus terlebih dahulu mengetahui keinginan dan kebutuhan pelanggan sehingga produk yang ditawarkan perusahaan sesuai dengan selera konsumen dan dapat diterima pasar sasaran. Strategi pemasaran sangat berpengaruh terhadap fungsi-fungsi lainnya yang ada dalam perusahaan. Penjualan merupakan salah satu strategi yang harus dilaksanakan oleh perusahaan untuk memasarkan barang dan jasa.

Menurut Chandra (2005:1) "pemasaran adalah proses sosial dan manajerial dimana individu dan kelompok mendapatkan apa yang mereka butuhkan dan inginkan melalui penciptaan penawaran dan pertukaran barang dan jasa yang bernilai satu sama lain. Menurut Kotler dan Armstrong (2004:16), menyatakan "pemasaran adalah analisis, perencanaan, penerapan, dan pengendalian terhadap program yang dirancang untuk menciptakan, membangun dan mempertahankan pertukaran dan hubungan yang menguntungkan dengan pasar sasaran dengan maksud untuk mencapai tujuan-tujuan organisasi". Menurut Boyd, dkk., (2000:4), "pemasaran adalah proses menganalisis, merencanakan, mengkoordinasikan dan mengendalikan program-program yang mencakup pengkonsepan produk, penetapan harga, promosi, dan distribusi dari produk, jasa dan gagasan yang dirancang untuk menciptakan dan memelihara pertukaran yang menguntungkan dengan pasar sasaran untuk mencapai tujuan perusahaan".

Berdasarkan pengertian tersebut, dapat disimpulkan bahwa pemasaran dalam arti kemasyarakatan adalah setiap kegiatan tukar menukar yang betujuan untuk memuaskan kebutuhan dan keinginan; sedangkan pengertian pemasaran dalam arti bisnis adalah sebuah sistem dari kegiatan bisnis yang dirancang untuk merencankaan, memberi harga, 
mempromosikan dan mendistribusikan produk yang dihasilkan untuk memenuhi kebutuhan dan keinginan konsumen. Jadi, konsumen harus benar-benar merasakan kebutuhannya terpenuhi supaya perusahaan memperoleh keseimbangan usaha yang bisanya sangat vital bagi keberhasilan untuk meraih tujuannya.

Pemasaran merupakan suatu kegiatan yang diarahkan untuk memenuhi kebutuhan manusia melalui pertukaran. Dari definisi di atas, ada tiga konsep penting yaitu: keinginan, kebutuhan dan pertukaran. Strategi pemasaran mempunyai hubungan yang erat dengan perilaku konsumen. Perilaku konsumen mempunyai implikasi sangat luas terhadap perumusan strategi pemasaran. Strategi pemasaran merupakan pendekatan pokok yang digunakan oleh unit bisnis dalam mencapai sasaran yang ditetapkan.

Keberhasilan suatu pemasar dapat diketahui dari strategi pemasarannya, yang mana strategi tersebut ada setelah para pemasar melihat bagaimana perilaku konsumen terhadap produk yang akan dimunculkan, apakah konsumen akan tertarik atau sebaliknya. Oleh karena pemasar harus membuat produk dan jasa yang baik, maka pengetahuan tentang konsumen dipengaruhi oleh sikap, norma subjektif dan kontrol perilaku sangat penting diketahui untuk usaha memasarkan barang atau jasa.

\section{B. Pengertian Perilaku Konsumen}

Pada hakekatnya, proses pembelian diawali dengan pengenalan kebutuhan dimana konsumen mengenali suatu masalah atau kebutuhannya sehingga konsumen dapat benarbenar merasakan perbedaan antara keadaan nyata dengan keadaan yang diinginkan. Agar konsumen merasa kebutuhannya terpenuhi maka pemasar perlu mengetahui apa yang menjadi keinginan mereka. Namun tidaklah mudah untuk mengetahui apa yang menjadi keinginan dan kebutuhan konsumen tersebut, karena konsumen mungkin saja menyatakan kebutuhan dan keinginan mereka sedemikian rupa tetapi tidak bertindak.

Menurut Peter dan Olson (2006:6) "perilaku konsumen adalah sebagai interaksi dinamis antara pengaruh dan kognisi, perilaku dan kejadian di sekitar kita dimana manusia melakukan aspek pertukaran dalam hidup meraka". Sutisna (2001:36) menyatakan bahwa "perilaku konsumen adalah perilaku pembelian yang berulang tanpa disertai dengan mencari informasi yang lebih banyak dan tanpa mengevaluasi pilihan dari alternatif yang tersedia". Umar (2001:50) menyebutkan "perilaku konsumen adalah suatu tindakan yang langsung dalam mendapatkan, mengkonsumsi, serta menghabiskan produk dan jasa, termasuk proses keputusan yang mendahului dan menyusuli tindakan tersebut".

Berdasarkan definisi di atas, terdapat tiga hal penting, yaitu perilaku konsumen adalah dinamis, perilaku konsumen melibatkan interaksi dan perilaku konsumen melibatkan pertukaran. Perilaku konsumen memiliki kepentingan khusus karena berhasrat mempengaruhi atau mengubah perilaku konsumen, termasuk mereka yang kepentingan utamanya adalah pemasaran, pendidikan dan perlindungan konsumen.

Perilaku konsumen dinamis berarti seorang konsumen, grup konsumen serta masyarakat luas selalu berubah dan bergerak sepanjang waktu. Perubahan tersebut, berpengaruh terhadap studi perilaku konsumen dan pengembangan strategi pemasaran. Dalam studi perilaku konsumen, salah satu implikasinya adalah bahwa generalisasi perilaku konsumen biasanya terbatas untuk satu jangka waktu tertentu, produk dan individu serta grup tertentu. Dalam pengembangan strategi pemasaran, sifat dinamis perilaku konsumen menyiratkan bahwa seseorang tidak boleh berharap bahwa suatu strategi pemasaran yang sama dapat memberikan hasil yang sama di sepanjang waktu, pasar dan industri. Walaupun hal ini tampak sederhana, namun banyak perusahaan gagal menyadari kebutuhan untuk mengantisipasi strategi pemasaran di pasar yang berbeda.

Perilaku konsumen melibatkan interaksi berarti untuk memahami konsumen dan mengembangkan strategi pemasaran yang tepat, perlu memahami apa yang dipikirkan oleh konsumen (kognisi), apa yang merek rasakan (pengaruh), apa yang mereka lakukan Aplikasi Theory of Planned Behavior Untuk Memprediksi Perilaku Mahasiswa Membeli Laptop 122 Lenovo (Studi Kasus: Mahasiswa FE- Unika Santo Thomas SU). Oleh : Darwis Tamba 
(perilaku), apa serta dimana (kejadian di sekitar) yang mempengaruhi serta dipengaruhi oleh apa yang dipikirkan, dirasakan dan dilakukan konsumen. Di sini, bisa hanya menganalisis dampak kejadian di sekitar terhadap pengaruh, kognisi dan perilaku seperti yang biasa dilakukan dalam riset pasar. Akan tetapi, dalam mengevaluasi seorang konsumen, pasar sasaran atau keseluruhan masyarakat. Analisis ketiga elemen tersebut sangat berguna untuk memahami dan mengembangan strategi pemasaran.

Perilaku konsumen melibatkan pertukaran berarti defenisi perilaku konsumen tetap konsisten dengan pengertian pemasaran yang menekankan pertukaran. Pemasaran berperan untuk menciptakan pertukaran dengan konsumen melalui formulasi dan penerapan strategi pemasaran. Strategi pemasaran yang sering digunakan perusahaan adalah produk, harga, promosi dan saluran distribusi.

\section{Faktor-faktor yang Mempengaruhi Perilaku Konsumen}

Secara sistematika proses keputusan konsumen merupakan ungkapan dari kompleksitas faktor-faktor yang mempengaruhi dan membentuk proses keputusan konsumen untuk membeli. Menurut Kotler dan Armstrong (2001:197), faktor-faktor yang mempengaruhi perilaku konsumen, adalah:

1. Faktor budaya. Faktor kebudayaan memberikan pengaruh paling luas pada keinginan dan perilaku konsumen orang pemasaran perlu memahami peranan dari budaya, sub budaya, dan kelas sosial pembeli.

a. Budaya. Budaya (culture) merupakan faktor penentu keinginan dan perilaku seseorang yang paling mendasar, muncul dari kebiasaan yang dialami dalam kehidupan seharihari. Setiap budaya mengandung sub budaya yang merupakan sekelompok orang dengan sistem nilai bersama berdasarkan pengalaman dan hidup yang sama.

b. Sub budaya. Sub budaya (sub culture) meliputi kewarganegaraan, agama, kelompok ras dan daerah geografis. Banyak sub kebudayaan yang membentuk segmen pasar penting, dan orang pemasaran yang disesuaikan dengan kebutuhan mereka. Hampir setiap masyarakat memiliki beberapa bentuk struktur kelas sosial.

c. Kelas sosial. Kelas sosial (social classes) merupakan bagian-bagian masyarakat yang relatif permanen dan tersusun rapi yang anggota-anggotanya mempunyai nilai-nilai, kepentingan dan perilaku yang sama. Kelas sosial terdiri dari kelas atas, menengah dan bawah. Kelas sosial atas adalah elit sosial yang hidup dari kekayaan warisan dan mempunyai latar belakang keluarga terkenal. Kelas menengah disusun oleh rata-rata pekerja kantoran yang tinggal di bagian kota yang lebih baik. Untuk bertahan dengan tren masa kini, mereka seringkali membeli produk-produk yang populer. Sedangkan kelas bawah adalah mereka yang standar hidupnya diambang kemiskinan, biasanya mereka membeli produk yang harganya relatif murah.

2. Faktor sosial. Perilaku konsumen juga dipengaruhi oleh faktor-faktor sosial seperti kelompok kecil, keluarga serta aturan dan status sosial konsumen. Perilaku seseorang dipengaruhi oleh banyak kelompok, yaitu:

a. Kelompok kecil. Kelompok kecil adalah kelompok yang secara langsung mempengaruhi dan dimiliki seseorang disebut kelompok keanggotaan. Beberapa di antaranya adalah kelompok primer yang memiliki interaksi reguler tetapi informal seperti keluarga, teman, tetangga, dan rekan sekerja. Sedangkan kelompok sekunder yang lebih formal dan memiliki sedikit interaksi reguler. Kelompok sekunder seperti: kelompok keagamaan, asosiasi profesional dan serikat buruh.

b. Keluarga. Keluarga adalah organisasi pembelian konsumen yang paling penting dalam masyarakat secara ekstensif. Orang pemasaran tertarik pada peran dan pengaruh seorang suami, istri maupun anak-anak dalam pembelian produk dan jasa yang berbeda. 
c. Peran dan status. Seseorang merupakan anggota berbagai kelompok, keluarga, klub dan organisasi. Posisi seseorang dalam setiap kelompok dapat diterapkan baik lewat perannya maupun statusnya dalam organisasi tersebut. Setiap peran membawa status yang mencerminkan penghargaan yang diberikan oleh masyarakat. Seseorang seringkali memilih produk yang menunjukkan status mereka dalam masyarakat.

3. Faktor pribadi. Keputusan seorang pembeli juga dipengaruhi oleh karakteristik pribadi seperti umur pembeli dan tahap siklus hidup, pekerjaan, situasi ekonomi, gaya hidup serta kepribadian dan konsep diri.

a. Umur dan siklus hidup. Seseorang mengubah barang dan jasa yang mereka beli selama hidup mereka. Selera terhadap makanan, pakaian, perabot dan rekreasi sering kali berhubungan dengan usia pembeli yang dibentuk oleh tahap siklus hidup keluarga. Orang pemasaran sering kali menetapkan pasar sasaran meraka berdasarkan tahap siklus dan mengembangkan produk sesuai rencana pemasaran untuk setiap tahapnya.

b. Pekerjaan. Pekerjaan seseorang mempengaruhi barang dan jasa yang dibelinya. Pekerja kasar cenderung membeli pakaian kerja kasar, sedangkan pekerja kantoran membeli pakaian kantor. Orang pemasaran mencoba mengidentifikasi kelompok-kelompok pekerja yang memiliki minat yang rata-rata lebih tinggi pada produk dan jasa yang mereka hasilkan.

c. Situasi ekonomi. Situasi ekonomi seseorang akan mempengaruhi pilihan produknya. Jika indikator-indikator ekonomi menunjukkan datangnya resesi, orang pemasaran dapat mengambil langkah-langkah untuk merancang ulang dan menetapkan kembali harga produk mereka dengan cepat.

d. Gaya hidup. Gaya hidup (life style) adalah pola kehidupan seseorang untuk memahami kekuatan-kekuatan ini kita harus mengukur dimensi activities (pekerjaan, hobi, belajar, olah raga, dan kegiatan sosial), interest (makan, model, keluarga dan reaksi), dan opinions (mengenai diri sendiri, masalah sosial, bisnis dan produk). Gaya hidup menampilkan pola perilaku seseorang dan interaksinya di dunia.

e. Kepribadian dan konsep diri. Kepribadian dan konsep diri tiap orang berbeda-beda saling mempengaruhi perilaku membelinya. Kepribadian (personality) adalah karakter psikologis yang unik, yang menghasilkan tanggapan yang relatif konsisten dan menetapkan (lasting) sifat-sifat seseorang seperti: kepercayaan diri, dominasi, beradaptasi dan agresivitas kepribadian bisa berguna menganalisis perilaku konsumen atas suatu produk maupun pilihan mereka. Dasar pemikiran konsep diri adalah apa yang dimiliki seseorang memberi kontribusi dan mencerminkan identitas mereka. Jadi untuk memahami perilaku konsumen para pemasar pertama kali harus memahami hubungan antara konsep diri dengan apa yang dimilikinya

b. Faktor psikologis. Pilihan membeli seseorang juga dipengaruhi oleh empat faktor psikologis utama, yaitu: motivasi, persepsi, pengetahuan serta keyakinan dan sikap.

b.1. Motivasi. Seseorang mempunyai banyak kebutuhan yaitu kebutuhan biologis yang muncul dari keadaan yang memaksa seperti rasa lapar, haus, atau merasa tidak nyaman. Kebutuhan lainnya bersifat psikologis muncul dari kebutuhan untuk diakui, dihargai, ataupun rasa memiliki. Kebanyakan kebutuhan ini tidak akan cukup kuat untuk memotivasi orang tersebut untuk bertindak pada satu waktu tertentu. Suatu kebutuhan akan menjadi motif apabila dirancang sampai suatu tingkat intensitas yang mencukupi. Sebuah motif (motive) dan dorongan (drive) adalah kebutuhan yang secara cukup dirancang untuk mengarahkan seseorang untuk mencari kepuasan.

b.2. Persepsi adalah proses seseorang individu memilih, mengorganisasikan dan menafsirkan masukan-masukan informasi untuk menciptakan sebuah gambaran 
mengenai sesuatu. Seseorang dapat membentuk persepsi-persepsi yang berbeda mengenai rangsangan yang sama.

b.3. Pembelajaran.

Pembelajaran (learning) menggambarkan perubahan perilaku individu yang muncul karena pengalaman para teoritikus pembelajaran mengatakan bahwa hampir semua perilaku manusia berasal dari belajar. Proses belajar berlangsung melalui dorongan (drive), rangsangan (stimuli), petunjuk (cues), tanggapan (responses)dan penguatan (reinforcement) yang selalu mempengaruhi.

b.4. Sikap

Keyakinan (belief) adalah pemikiran deskriptif seseorang mengenai sesuatusesuatu keyakinan dapat didasarkan pada pengetahuan nyata, opini, atau kepercayaan dan mungkin saja membawa muatan emosional sikap menggambarkan penilaian perasaan dan kecenderungan yang relatif konsisten dari seseorang atau sebuah objek atau gagasan. Sikap menempatkan seseorang dalam suatu kerangka pemikiran mengenai suka, atau tidak sukanya akan sesuatu mendekati menjauhi mereka.

\section{Proses Pengambilan Keputusan Pembelian}

Tahap-tahap yang dilewati pembeli untuk mencapai keputusan membeli ditunjukkan pada gambar 2.1, di mana konsumen melewati lima tahap: "pengenalan kebutuhan, pencarian informasi, evaluasi alternatif, keputusan membeli dan tingkah laku pasca pembelian" (Kotler dan Armstrong, $2004: 224$ ).

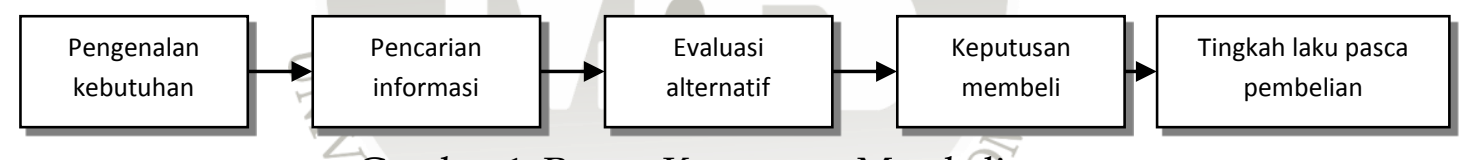

Gambar 1. Proses Keputusan Membeli

Sumber: Kotler, Philip; Armstrong, Gary. Dasar-dasar Pemasaran. (2004:224).

1. Pengenalan kebutuhan. Proses pembelian bermula dari pengenalan kebutuhan. Pembeli merasakan adanya perbedaan antara keadaan aktual dan sejumlah keadaan yang diinginkan. Kebutuhan itu dapat dipicu oleh stimulan internal ketika salah satu kebutuhan normal naik ke tingkatan yang cukup tinggi sehingga menjadi pendorong. Kebutuhan juga dapat dipicu oleh rangsangan eksternal. Setelah mengumpulkan informasi, pemasar dapat mengidentifikasi faktor-faktor yang memicu ketertarikan terhadap produk dan mengembangkan program pemasaran yang melibatkan faktor-faktor tersebut.

2. Pencarian informasi. Tahap proses pengambilan keputusan keputusan dimana konsumen bergerak untuk mencari informasi tambahan, meningkatkan perhatian atau mungkin pula mencari informasi secara aktif. Jika dorongan konsumen kuat dan produk yang memenuhi kebutuhan berada dalam jangkauannya, ia cenderung akan membelinya. Jika tidak, konsumen akan menyimpan kebutuhan itu ke dalam ingatan atau mengerjakan pancarian informasi yang berhubungan dengan kebutuhan tersebut. Konsumen dapat memperoleh informasi dari berbagai sumber. Sumber itu meliputi: sumber pribadi (keluarga, teman, tetangga, rekan kerja), sumber komersial (iklan, penjual, pengecer, bungkus, situs web dan lain sebagainya), sumber publik (media massa organisasi pemberi peringkat), dan sumber berdasarkan pengalaman (memegang, meneliti atau menggunakan produk). Pengaruh relatif di antara sumber informasi itu berbeda-beda di antara berbagai produk dan pembeli. Konsumen biasanya menerima sebagian besar informasi dari sumber komersial yang dikendalikan oleh pemasar. Namun demikian, sumber yang paling efektif cenderung bersifat pribadi Sumber komersial bisanya 
memberikan informasi kepada pembeli, sedangkan sumber pribadi memberikan legitimasi atau mengevaluasi produk bagi pembeli.

3. Evaluasi alternatif. Tahap keputusan pembeli dimana konsumen menggunakan informasi untuk mengevaluasi berbagai merek alternatif dalam serangkaian pilihan. Dalam hal ini, pemasar perlu memahami proses pengevaluasian alternatif, yaitu cara konsumen memproses informasi yang menghasilkan berbagai pilihan merek. Sikap konsumen terhadap sejumlah merek tertentu terbentuk melalui beberapa prosedur evaluasi. Cara konsumen memulai usaha mengevaluasi alternatif pembelian tergantung pada konsumen individual dan situasi pembelian tertentu. Dalam beberapa kasus, konsumen menggunakan kalkulasi yang cermat dan pikiran yang logis. Dalam waktu yang lain, konsumen bersangkutan mengerjakan sedikit atau tidak mengerjakan evaluasi sama sekali, melainkan mereka membeli secara impulsif atau bergantung pada intuisi. Terkadang konsumen membuat keputusan sendirian, kadang tergantung pada teman, petunjuk konsumen, atau penjual untuk mendapatkan saran pembelian.

4. Keputusan membeli. Pada tahap pengevaluasian, konsumen menyusun peringkat merek dan membentuk kecenderungan (niat) pembelian. Secara umum, keputusan pembelian konsumen akan membeli merek yang paling disukai, tetapi ada dua faktor yang muncul di antara kecenderungan pembelian dan keputusan pembelian. Faktor pertama adalah sikap orang lain dan kedua adalah faktor situasi yang tak terduga. Konsumen mungkin membentuk kencenderungan pembelian berdasarkan pada pendapatan yang diharapkan, harga, dan manfaat produk yang diharapkan.

5. Tingkah laku pasca pembelian. Tahap keputusan pembelian konsumen melakukan tindakan lebih lanjut setelah pembelian berdasarkan pada kepuasan atau ketidakpuasan. Dalam hal ini, pekerjaan pemasar tidak berhenti pada saat produk dibeli. Setelah membeli produk, konsumen akan merasa puas atau tidak puas dan akan masuk ke perilaku setelah pembelian yang penting diperhatikan oleh tenaga pemasar. Jika produk jauh berada di bawah harapan konsumen, maka konsumen kecewa, jika produk memenuhi harapannya, konsumen terpuaskan, jika melebihi harapannya, maka konsumen merasa sangat senang.

\section{E. Theory of Planned Behavior}

Theory of reasoned action (Fisbein dan Ajzen) merupakan suatu model yang digunakan untuk memprediksi minat dan perilaku. Menurut theory of reasoned action perilaku (behavior) seseorang tergantung pada minatnya (intention), sedangkan minat untuk berperilaku sangat tergantung pada sikap dan norma subjektif atas perilaku. Pada sisi lain keyakinan atas akibat perilaku sangat mempengaruhi sikap dan norma subjektif. Minat dan perilaku konsumen dipengaruhi oleh faktor internal individu dan faktor eksternal (lingkungan sosial). Faktor internal individual tercermin dari sikap seseorang, sedangkan faktor eksternal tercermin dari pengaruh orang lain (norma subjektif) terhadap perilaku. Untuk menganalisis sikap dan norma subjektif, diperlukan sebuah model, salah satunya adalah model multiatribut dari Firhbein.

Theory of reasoned action diasumsikan bahwa hampir semua perilaku di bawah kontrol kemajuan seseorang untuk melakukan tindakan tertentu. Namun kenyataannya masih banyak perilaku tidak dalam kontrol penuh orang tersebut. Beberapa perilaku yang mengalami kekurangan seperti yang berkaitan dengan keahlian, kemampuan, pengetahuan dan perencanaan yang baik. Dalam perilaku yang lain mungkin terdapat hambatan eksternal seperti waktu atau kesempatan yang mungkin membatasai untuk mencapai sasaran, maka untuk mengakomodasi faktor penghambat tersebut model dari Theory of Reasoned Action menjadi Theory of Planned Behavior. Theory of Reasoned Action (TRA), dikembangkan pada tahun 1967, selanjutnya teori tersebut terus direvisi dan diperluas oleh Icek Ajzen dan Martin Fishbein. Pada tahun 1980, teori tersebut digunakan untuk mempelajari perilaku manusia dan untuk mengembangkan intervensi-intervensi yang lebih tepat. Pada tahun 1988, hal lain 
ditambahkan kontrol perilaku pada model reasoned action yang sudah ada tersebut, kemudian dinamai Theory of Planned Behavior (TPB).

Prediksi perilaku konsumen secara akurat dilakukan para ahli dalam berbagai penelitian. Theory of Planned Behavior (teori perilaku terencana) merupakan pengembangan dari Theory of Reasoned Action (teori tindakan beralasan) yang bertujuan untuk mengatasi masalah yang tidak sepenuhnya berada dibawah kontrol seseorang yang belum lengkap dalam teori tindakan beralasan.

Inti Theory of Planned Behavior, tetap berada pada faktor intensi perilaku namun determinan intensi tidak hanya sikap dan norma subjektif melainkan juga aspek kontrol perilaku yang dirasakan (perceived behavior control). Namun kontrol keperilakuan yang dirasakan dianggap mempunyai implikasi baik secara langsung maupun tidak langsung untuk memprediksi perilaku konsumen. Ketiga komponen, yaitu sikap, norma subjektif dan kontrol perilaku yang dirasakan berinteraksi dan menjadi determinan bagi minat yang pada gilirannya akan menentukan apakah perilaku yang bersangkutan akan dilakukan atau tidak.

Menurut Achmat (2008:5), komponen dalam theory planned behavior adalah:

1. Sikap konsumen. Sikap dianggap sebagai variabel pertama dari perilaku. Sikap adalah kepercayaan positif atau negatif untuk menampilkan suatu perilaku tertentu. Kepercayaan atau beliefs ini disebut behavioral beliefs. Seorang individu akan berniat untuk menampilkan suatu perilaku tertentu, ketika seseorang menilainya secara positif. Sikap ditentukan oleh kepercayaan individu mengenai konsekuensi dari menampilkan suatu perilaku (behavioral beliefs), ditimbang berdasarkan hasil evaluasi terhadap konsekuensinya (outcome evaluation). Sikap tersebut dipercaya memiliki pengaruh langsung terhadap perilaku dan dihubungkan dengan norma subjektif dan perceived behavioral control.

2. Norma Subjektif. Norma subjektif diasumsikan sebagai suatu fungsi dari beliefs yang spesifik seseorang setuju atau tidak setuju untuk menampilkan suatu perilaku. Kepercayaan yang termasuk dalam norma subjektif (normative beliefs). Seorang individu akan berniat menampilkan suatu perilaku tertentu, jika mempersepsi bahwa orang lain yang penting berpikir bahwa ia seharusnya melakukan hal tersebut.

3. Kontrol Perilaku. Seseorang memiliki kendali sepenuhnya, ketika tidak terdapat hambatan apapun untuk menampilkan suatü perilaku. Dalam keadaan ekstrim yang sebaliknya, mungkin sama sekali tidak terdapat kemungkinan mengendalikan suatu perilaku, karena tidak adanya kesempatan, karena tidak adanya sumber daya atau ketrampilan. Perceived behavioral control menunjuk suatu derajat dimana seorang individu merasa bahwa tampil atau tidaknya suatu perilaku di bawah kendalinya. Orang cenderung tidak akan membentuk suatu intensi yang kuat untuk menampilkan suatu perilaku tertentu, jika tidak memiliki kesempatan untuk melakukannya meskipun bersikap positif dan percaya bahwa orang lain yang penting baginya akan menyetujuinya. Jalur langsung dari perceived behavioral control ke perilaku diharapkan muncul ketika terdapat keselarasan antara persepsi mengenai kendali dan kendali yang aktual dari seseorang atas suatu perilaku.

Hubungan ketiga komponen dalam Theory of Planned Behavior (TPB) dapat dilihat pada gambar berikut: 


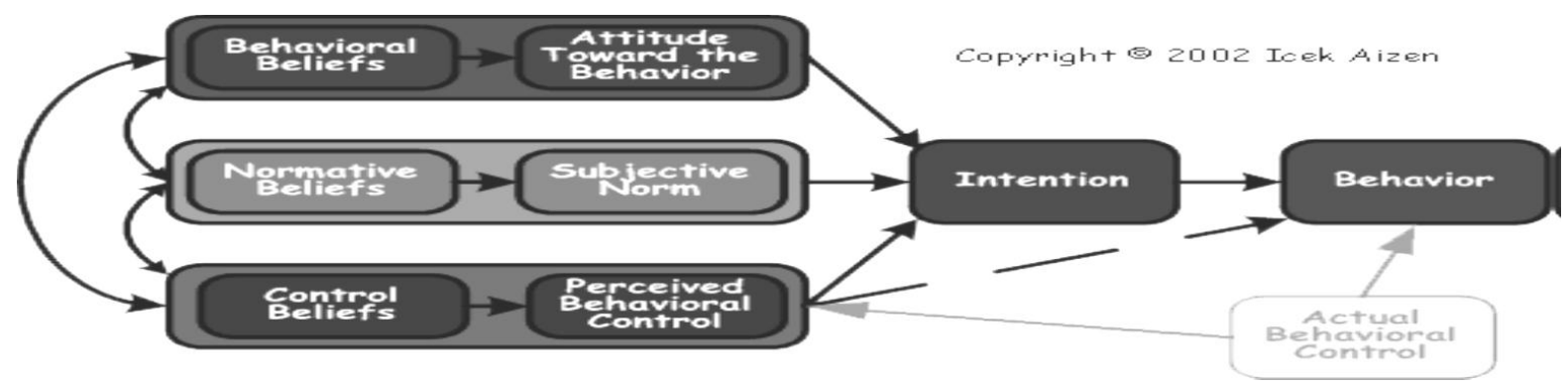

Gambar 2 Theory of Planned Behavior

Sumber: Achmad, Zakarija. Theory of Planned Behavior, (2008:25)

Tanda panah yang solit menunjukkan bahwa variabel sikap (Ab) normal Subjektif (SN) dan kontrol perilaku yang dirasakan (PC) berhubungan secara tidak langsung terhadap perilaku (B) melalui minat dan niat (BI). Namun demikian kontrol perilaku yang dirasakan (PC) dapat saja berhubungan langsung terhadap perilaku (B) tanpa melalui niat berperilaku (BI) yang ditunjukkan oleh tanda panah terputus. Niat merupakan variabel yang menyebabkan terjadinya perilaku dari sistem maupun variabel lainnya.

\section{F. Kerangka Pemikiran}

Kerangka pemikiran mengacu pada model Theory of Planned Behavior (Achmad, Zakarija,2008) yaitu :

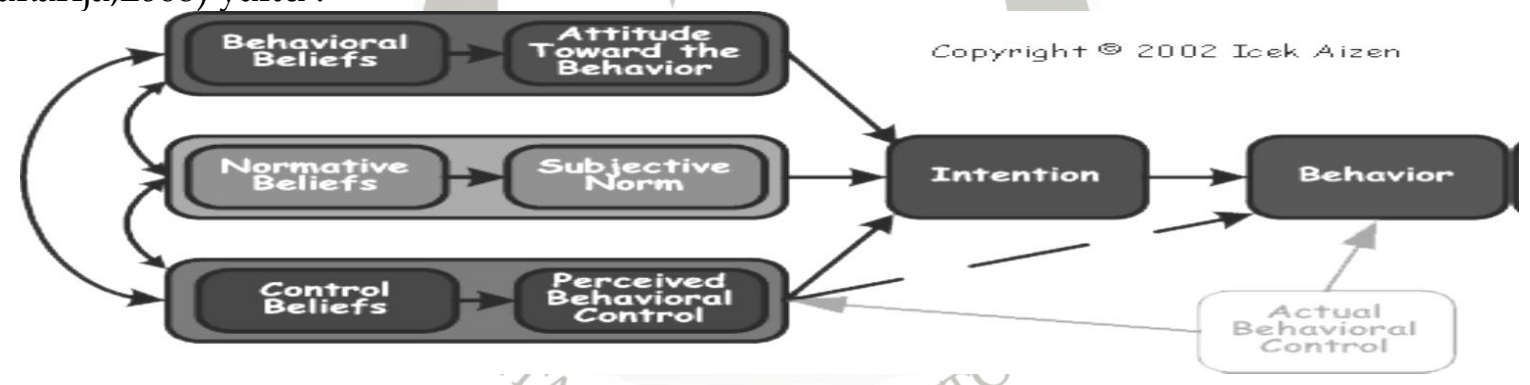

Gambar 3. Kerangka pemikiran

Sumber: Achmad, Zakarija.T Theory of Planned Behavior, (2008:25)

\section{METODE PENELITIAN}

\section{A. Populasi dan Sampel}

Populasi merupakan keseluruhan objek yang akan diteliti. Populasi dalam penelitian ini adalah seluruh mahasiswa FE- Unika St. Thomas SU. Sampel adalah bagian dari populasi yang dianggap dapat mewakilinya. Sampel penelitian ditentukan berdasarkan kesalahan maksimum yang diinginkan, dengan rumus (Supranto, 2001: 113):

$$
\begin{aligned}
n & =\left(\frac{Z_{\alpha / 2}{ }^{2} \times \sigma}{\varepsilon}\right)^{2} \\
& =\left(\frac{1,96 \times 0,5}{0,1}\right)^{2} \\
& =96,04 \text { orang }
\end{aligned}
$$

Dalam penelitian ini, tingkat keyakinan ditetapkan $95 \%\left(\alpha=5 \%\right.$, sehingga $\left.Z^{1} / 2 \alpha=1,96\right)$, kesalahan (error) maksimum $(\varepsilon)=0,1$ dan standar deviasi $(\sigma)=0,5$; maka jumlah sampel yang dibutuhkan $(\mathrm{n})=96,04$ dibulatkan menjadi 96 orang. Teknik penentuan sampel adalah purposive sampling, yaitu sampel diambil secara merata dari masing-masing stambuk.

\section{B. Operasionalisasi Variabel}


Operasionalisasi variabel merupakan batasan pokok permasalahan yang akan diteliti sesuai perumusan masalah. Variabel yang akan diteliti dalam penelitian ini adalah:

1. Sikap konsumen $(\mathrm{Ab})$

Sikap konsumen $(\mathrm{Ab})$ menggambarkan kecenderungan yang dipelajari dari seseorang untuk berperilaku terhadap hal yang disenangi atau tidak disenangi dalam membeli laptop Lenovo. Sikap konsumen diukur dari:

a. Keyakinan (bi) adalah suatu ide yang dianut konsumen untuk membeli laptop yang cenderung menimbulkan konsekuensi dari atribut produk tersebut.

b. Evaluasi akibat (ei) adalah penilaian seorang konsumen terhadap tiap-tiap atribut keyakinan untuk memutuskan pembelian laptop Lenovo.

Indikator yang diamati tentang variabel keyakinan (bi) dan evaluasi akibat (ei), yaitu kecanggihan teknologi, garansi, purna jual, kemudahan tempat service dan kemudahan sparepart.

2. Norma subjektif (SN)

Norma subjektif (SN) adalah gagasan orang lain yang menghendaki konsumen untuk membeli laptop Lenovo. Norma subjektif diukur dari:

a. Keyakinan normatif (NBj) adalah gagasan yang diterima dari kelompok referen yang berpendapat bahwa seyogyanya atau tidak seyogyanya membeli laptop Lenovo.

b. Motivasi (MCj) adalah dorongan yang kuat, untuk menuruti pengaruh kelompok referen untuk membeli laptop Lenovo.

Indikator yang diamati tentang variabel keyakinan normatif (NBj) dan motivasi (MCj) yaitu keluarga, teman dekat, rekan mahasiswa, tetangga, dan tenaga pemasar.

3. Kontrol perilaku (PC)

Kontrol perilaku yang dirasakan (PC) yaitu merupakan salah satu persepsi dari keberadaan atau ketidakberadaan dari sumber-sumber dan kesempatan yang diperlukan untuk menghasilkan suatu perilaku. Kontrol perilaku yang dirasakan dapat diukur dengan dua variabel yaitu keyakinan kontrol terhadap suatu tindakan (Pi) dan kemudahan yang dirasakan terhadap suatu atribut (Ci). Indikatornya: kecanggihan teknologi, garansi, purna jual, kemudahan tempat service dan kemudahan sparepart.

4. Perilaku konsumen (BI) adalah perhatian atau kecenderungan seseorang untuk membeli laptop Lenovo. Perilaku terbentuk dari pengaruh sikap konsumen, norma subjektif dan perilaku yang dirasakan.

Pengukuran variabel penelitian mengacu pada skala Thurstone dengan lima tingkatan jawaban yaitu: sangat tidak setuju (STS), tidak setuju (TS), Netral (N), setuju (S), sangat setuju (SS), dengan skor $-2,-1,0,1,2$.

\section{Teknik Pengumpulan Data}

Pada penelitian ini digunakan metode pengumpulan data primer melalui metode survei yang terdiri dari wawancara dan kuisioner sebagai berikut :

1. Wawancara. Wawancara merupakan teknik pengumpulan data dalam metode survei yang menggunakan pertanyaan secara lisan kepada subyek penelitian.

2. Koesioner. Koesioner merupakan metode pengumpulan data yang diperoleh dari jawaban yang diberikan responden berdasarkan daftar pertanyaan yang telah disusun sebelumnya. Pada penelitian ini digunakan kuisioner dengan skala Likert dimana pernyataan-pernyataan dalam kuisioner dibuat dengan nilai 1 sampai dengan 5 untuk mewakili pendapat responden .

3. Dokumentasi. Mengumpulkan data dari berbagai sumber yang relevan dengan topic yang diteliti seperti studi pustaka.

\section{Teknik Analisis}


Uji validitas berguna untuk mengetahui ketepatan hasil kuesioner. Pengujian validitas tiap butir digunakan analisis item, yaitu mengkorelasikan skor tiap butir dengan skor total, yang merupakan jumlah tiap skor butir. Teknik korelasi untuk menentukan validitas item ini sampai sekarang merupakan teknik yang paling banyak digunakan. Selanjutnya dalam memberikan interprestasi terhadap koefisien korelasi, dimana item yang mempunyai korelasi positif dengan kriteria (skor total) serta korelasi yang tinggi, menunjukkan bahwa item tersebut mempunyai validitas yang tinggi pula. Menurut Sugiyono (2005:114), "jumlah anggota sampel digunakan sekitar 30 orang". Biasanya, syarat minimum yang dianggap memenuhi syarat adalah jika nilai $r=0,30$ jadi korelasi antara butir dengan skor total kurang dari 0,30, maka butir dalam instrumen tersebut dinyatakan tidak valid. Untuk menghitung koefisien korelasi digunakan "korelasi product moment" dengan rumus:

$$
r_{x y}=\frac{n \sum X Y-\left(\sum X\right)\left(\sum Y\right)}{\sqrt{\left\{n \sum X^{2}-\left(\sum X\right)^{2}\right\}}\left\{n \sum Y^{2}-\left(\sum Y\right)^{2}\right\}}
$$

Keterangan: $\mathrm{X}=$ skor tiap butir, $\mathrm{Y}=$ skor total butir dan $\mathrm{n}=$ jumlah responden

Uji reliabilitas berguna untuk mengetahui apakah hasil kuesioner dapat dipercaya atau tidak. Pengujian reliabilitas instrumen dapat dilakukan secara internal yang diuji dengan menganalisis konsistensi butir-butir yang ada pada instrumen dengan teknik tertentu.

Menurut Sugiyono (2005:122), "pengujian reliabilitas dengan internal consistency, dilakukan dengan cara mencoba instrumen sekali saja, kemudian yang data diperoleh dianalisis dengan teknik tertentu. Hasil analisis dapat digunakan untuk memprediksi reliabilitas instrumen. Pengujian reliabilitas instrumen dilakukan dengan teknik belah dua dari Spearmen Brown dengan rumus:

$$
r i=\frac{2 r b}{1+r b}
$$

Keterangan $: r_{i}=$ reliabilitas internal seluruh instrumen

$\mathrm{rb}=$ korelasi product moment antara belahan pertama dan kedua.

Perhitungan reliabilitas pada penelitian ini menggunakan analisis yang dikembangkan oleh Alpha Cronbach. Pada uji ini dinilai reliabel jika lebih besar dari 0,5 di mana kriteria sebagai berikut:

$\alpha \geq 0,50$ artinya instrumen reliabel.

$\alpha<0,50$ artinya instrumen tidak reliabel.

\section{F. Metode Deskriptif}

Teknik analisis data yang digunakan dalam penelitian ini adalah metode analisis deskriptif. Metode deskriptif dilakukan dengan mengumpulkan data, menginterprestasikan, mengolah dan menganalisis data dengan menggunakan theory of planned behavior, dengan rumus :

$$
\begin{aligned}
(B \approx B I) & =W 1 A b+W 2 S N+W 3 P C \text { atau } \\
& =W 1 \sum b i . e i+W 2 \sum N B j . M C j+W 3 \sum P i . C i
\end{aligned}
$$

Keterangan $: \mathrm{B}=$ perilaku tertentu, $\mathrm{Bi}=$ Minat konsumen, $\mathrm{SN}=$ Norma subjektif, $\mathrm{Ab}=$ Sikap konsumen, $\mathrm{PC}=$ Kontrol perilaku yang dirasakan, W1, W2 dan W3 = Nilai probabilitas dari masing-masing variabel, tanda $(\approx)$ menunjukkan bahwa kedua variabel $\mathrm{B}$ dan BI berhubungan. Dimana nilai Ab, SN, PC, dan W1, W2, W3 dapat dicari dengan rumus sebagai berikut :

$$
A b=\sum_{t=1}^{n}(b i) .(e i)
$$

Keterangan: $\mathrm{Ab}=$ Sikap konsumen terhadap perilaku, $\mathrm{bi}=$ Keyakinan akan perilaku, ei = Evaluasi terhadap atribut i, n = Jumlah keyakinan konsumen 


$$
S N=\sum_{t=1}^{n} N B j \cdot M C j
$$

Keterangan $: \mathrm{SN}=$ Norma subjektif yang menghendaki perilaku tertentu., $\mathrm{NBj}=$ Keyakinan normatif dari pengaruh kelompok referen $\mathrm{j}, \quad \mathrm{MCj}=$ Motivasi menurut referen $\mathrm{j}, \quad \mathrm{n}=$ Jumlah kelompok preferen

$$
P C=\sum_{i=1}^{n} P i . C i
$$

Keterangan: $\mathrm{PC}=$ Kontrol perilaku yang dirasakan,$\quad \mathrm{Pi}=$ Keyakinan kontrol terhadap tindakan $\mathrm{i}, \mathrm{Ci}=$ Kemudahan yang dirasakan terhadap atribut $\mathrm{i}, \mathrm{n}=$ Jumlah kontrol perilaku yang dirasakan

$$
\begin{aligned}
& G M A b=\frac{\text { Total } b_{i}+\text { Total } e_{i}}{2 \times \text { Jumlah atribut }} \\
& \text { GMSN }=\frac{\text { Total Nbj }+ \text { Total Mcj }}{2 \times \text { Jumlah atribut }}
\end{aligned}
$$

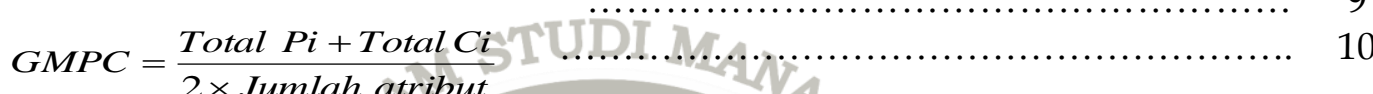

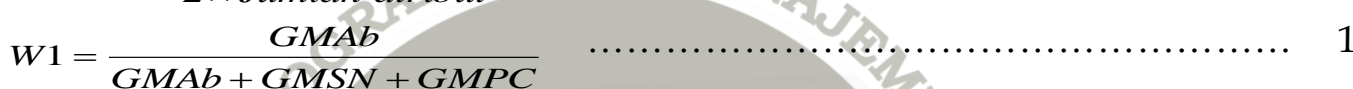

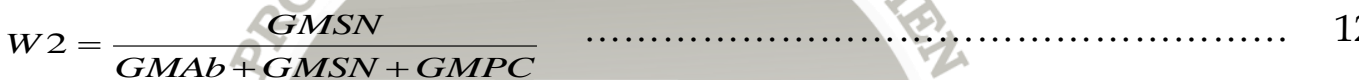

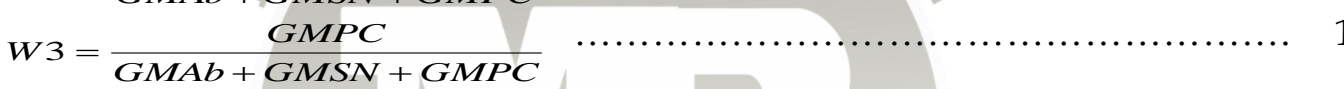

Untuk mengetahui kekuatan di setiap sub variabel yang akan diuji maka kriteria penentuan interprestasi/penilaian dari setiap sub variabel atau atribut berdasarkan Range Henerson adalah sebagai berikut:

$$
\begin{array}{ll}
1,1<\mathrm{Ab} / \mathrm{SN} / \mathrm{PC} \leq 2,0 & \text { Sangat positif } \\
0,1<\mathrm{Ab} / \mathrm{SN} / \mathrm{PC} \leq 1,0 & \text { Positif } \\
-0,1<\mathrm{Ab} / \mathrm{SN} / \mathrm{PC} \leq-1,0 & \text { Negatif } \\
-1,1<\mathrm{Ab} / \mathrm{SN} / \mathrm{PC} \leq-2, & \text { Sangat negatif }
\end{array}
$$

\section{HASIL DAN PEMBAHASAN PENELITIAN}

Fakultas Ekonomi Universitas Katolik Santo Thomas Sumatera Utara (FE Unika Santo Thomas SU) merupakan pengembangan dari Akademi Sekretaris dan Manajemen (ASM) Katolik Budi Murni yang berdiri mulai 16 Mei 1980, dengan surat izin operasional dari Kopertis Wilayah I Nomor: 066/PP/KOP.I/1982. Selanjutnya pada tahun 1984, ASM Katolik Budi Murni memperoleh status terdaftar dari Menteri Pendidikan dan Kebudayaan RI Nomor: 069/0/1984. Kemudian Keuskupan Agung Medan mengembangkan ASM Katolik Budi Murni menjadi FE Unika Santo Thomas SU dengan surat persetujuan Kopertis Wilayah I Nomor: 091/SK/KOP.I/1984 pada tanggal 23 April 1984, yang berlokasi di Jl. Jend. S. Parman 107 Medan. Pada tahap ini Fakultas Ekonomi terdiri dari Jurusan Manajemen Perkantoran Program Studi D3, Jurusan Program Studi Manajemen S1 dan Jurusan Akuntansi S1.

Pada tahun 1986, Jurusan Manajemen Program Studi S1 dan Jurusan Akuntansi Program Studi S1 memperoleh status terdaftar dengan SK Menteri Pendidikan dan Kebudayaan RI Nomor: 0387/0/1986 dan jurusan Manajemen Program Studi Manajemen Perkantoran Program D3 memperoleh status diakui dengan SK Menteri Pendidikan dan Kebudayaan Nomor: 006/0/1990 tanggal 4 Januari 1990. Sejak tahun 1984 sampai dengan 1992, Fakultas Ekonomi menempati di Jl. Jend. S. Parman 107, Medan dengan jumlah mahasiswa sekitar 2.600 orang. Sehubungan dengan perkembangan jumlah mahasiswa, pada tahun 1993, Unika Santo Thomas SU mendirikan kampus baru Fakultas Ekonomi di Jl. 
Setiabudi Tanjung Sari. Kampus baru Fakultas Ekonomi terdiri dari bangunan berlantai tiga dengan daya tampung yang lebih besar.

Visi yang diemban oleh Yayasan Santo Thomas adalah perwujudan lembaga yang bersih, tangguh dan setia serta mengutamakan martabat dan kesejahteraan manusia melalui pendidikan, penelitian, sosial dan keagamaan. Misinya adalah:

1. Menyelenggarakan pengelolaan Yayasan yang transparan, akuntabel, dan tanggap terhadap tanda-tanda zaman.

2. Menyelenggarakan pendidikan tinggi yang bermutu, berdisiplin, profesional dan mempersiapkan alumni memasuki lapangan kerja.

3. Mendorong peningkatan mutu dari kehidupan beragama dan bermasyarakat.

Berdasarkan visi dan misi Yayasan tersebut, kemudian ditetapkan visi Unika Santo

Thomas SU adalah masyarakat akademik yang unggul, kompetitif dan beriman. Misinya adalah:

1. Menyelenggarakan pendidikan dan pengajaran untuk membentuk manusia yang berkualitas, profesional, berkepribadian Indonesia, dan berakhlak mulia.

2. Menyelenggarakan dan mengembangkan jiwa berpikir ilmiah dan kewirausahaan serta keahlian dalam bidang ilmu pengetahuan teknologi dan informasi.

3. Melaksanakan penelitian untuk pengembangan ilmu dan teknologi demi bangsa dan kesejahteraan masyarakat.

4. Melaksanakaan pengabdian kepada masyarakat sebagai penerapan ilmu dan teknologi dalam tataran lokal, nasional dan global.

5. Menjalin kerjasama dengan berbagai institusi lokal dan global untuk meningkatkan mutu pendidikan, penelitian dan pengabdian kepada masyarakat.

6. Melaksanakan pembinaan masyarakat akademi yang beriman dan berkarakter.

Visi pendirian FE Unika Santo Thomas SU adalah terselenggaranya pendidikan ilmu ekonomi yang berlandaskan ajaran dan moral Katolik untuk menghasilkan lulusan yang berintegritas tinggi dan sanggup mengabdikan diri bagi negara, bangsa dan masyarakat. Misinya adalah:

1. Mewujudkan penyelenggaraan pendidikan akademi dan profesional di bidang ilmu ekonomi yang berkualitas tinggi yang berlandaskan keimanan, kejujuran, ketaqwaan dan wawasan kebangsaan.

2. Mewujudkan penyelenggaraan penelitian dan pengembangan ilmu ekonomi untuk menjawab tantangan dan kebutuhan masyarakat, dan

3. Menyelenggarakan tugas-tugas pengabdian pada masyarakat sebagai penerapan ilmu ekonomi.

Sasaran FE Unika Santo Thomas SU adalah:

1. Membentuk Sarjana Ekonomi dan Ahli Madya yang memiliki kemampuan dan keterampilan manajerial yang berkualitas berlandaskan ajaran dan moral luhur.

2. Membentuk Sarjana Ekonomi dan Ahli Madya yang memiliki ilmu pengetahuan yang komprehensif di bidang ilmu ekonomi dan dapat diterima di pasar kerja.

3. Membentuk Sarjana Ekonomi dan Ahli Madya dengan tingkat prestasi yang memuaskan dan mempunyai daya saing yang tinggi.

Lulusan FE Unika Santo Thomas SU diupayakan memiliki kompetensi akademik sebagai berikut:

1. Memiliki kualitas keilmuan dan keahlian dalam bidang ekonomi.

2. Memiliki daya saing di bidang ekonomi dalam memasuki lapangan kerja untuk peningkatan kesejahteraan dan martabat manusia. 
3. Memiliki kualitas keimanan yang baik, sehingga menjadi sarjana dan ahli madya Ekonomi yang berakhlak mulia, jujur, adil, serta mengutamakan kebenaran.

4. Memiliki kualitas kewirausahaan yang mandiri, sehingga mampu menciptakan lapangan kerja guna pembangunan dunia usaha.

5. Memiliki karakteristik dan disiplin yang tinggi sebagai tenaga profesional.

Visi dan misi program studi adalah:

1. Visi program studi manajemen S1. Visi program studi manajemen S1 adalah menyelenggarakan akademik sebagai pusat penelitian intelektual dan pusat penyebaran dan pengembangan ilmu manajemen berdasarkan moral kristiani. Misinya adalah menyelenggarakan pendidikan guna menghasilkan sumber daya manusia yang unggul, jujur memiliki integritas degan melakukan penelitian dan pengembangan pengetahuan manajemen yang mampu menyerap perkembangan sesuai kebutuhan masyarakat dan mengabdikannya berdasarkan moral kristiani. Kompetensi akademik program studi manajemen S1:
a. Mampu sebagai manajer pemasaran, keuangan, sumber daya manusia dan operasi dalam mengelola suatu perusahaan.
b. Mampu merencanakan, mengorganisasikan, mengevaluasi, dan mengimplemen tasikan program kerja dalam perusahaan.
c. Mampu membuat keputusan yang akurat.
d. Mampu bekerja sama dalam teamwork.

2. Visi program studi akuntansi S1. Visi program studi akuntansi S1 adalah menyelenggarakan pendidikan akuntansi yang berlandaskan ajaran dan moral Katolik untuk menghasilkan lulusan yang berintegritas tinggi dan berkemampuan tinggi serta sanggup mengabdikan diri untuk kepentingan negara, bangsa, dan masyarakat. Misinya adalah (1) mewujudkan penyelenggaraan pendidikan akuntansi dan profesional di bidang akuntansi, (2) mewujudkan penyelenggaraan penelitian dan pengembangan akuntansi untuk menjawab tantangan dan kebutuhan masyarakat, dan (3) menyelenggarakan tugastugas pengabdian pada masyarakat sebagai penerapan akuntansi. Kompetensi akademik program studi akuntansi S1 adalah:
a. Mampu menyusun laporan keuangan perusahaan
b. Mampu mengaudit laporan keuangan perusahaan
c. Mampu menyusun laporan pajak perusahaan
d. Mampu bekerja sama dalam tim.

3. Visi program studi manajemen administrasi perkantoran D3. Visi program studi manajemen administrasi perkantoran D3 adalah menyelenggarakan pendidikan profesi yang menghasilkan lulusan ahli madya yang berintegritas tinggi di bidang manajemen perkantoran, dan sanggup mengabdikan diri untuk terwujudnya administrasi yang efisien dan efektif yang berlandaskan moral kekatolikan. Misi adalah (1) mewujudkan penyelenggaraan pendidikan manajemen perkantoran yang kompeten dan berdaya saing tinggi di lingkungan kerja, (2) melaksanakan pengabdian kepada masyarakat sebagai perwujudan keahlian dan keterampilan yang dimiliki. Kompetensi akademiknya adalah:
a. Mampu melaksanakan tugas dan tanggungjawab teknis di bidang kesekretariatan dan administrasi kantor.
b. Mampu menggunakan sarana dan prasarana kantor
c. Mampu bekerja dalam tim.

4. Visi program studi akuntansi D3. Visi program studi akuntansi D3 adalah menyelenggarakan pendidikan akuntansi berlandaskan ajaran dan moral Katolik untuk menghasilkan lulusan yang berintegrasi tinggi, berkemampuan dan sanggup mengabdikan diri untuk kepentingan negara, bangsa dan masyarakat. Misinya adalah untuk (1) 
Volume 17 Nomor 2

(b) melaksanakan pengabdian kepada masyarakat sebagai perwujudan dan keterampilan yang dimiliki. Kompetensi akademiknya adalah:

a. Mampu menyusun pencatatan akuntansi dan penyusunan laporan keuangan perusahaan jasa, dagang dan manufaktur.

b. Mampu menyusun SPT tahunan wajib pajak.

c. Mampu mengoperasikan salah satu software accounting.

d. Mampu bekerja dalam tim.

\section{A. Hasil Uji Validitas dan Reliabilitas}

Berdasarkan hasil pengolahan data dengan menggunakan program SPSS (Statistical Program for Social Sciences) versi 17,0, diperoleh hasil uji validitas secara simultan mengenai variabel sikap, norma subjektif dan kontrol perilaku yang dirasakan mahasiswa disajikan pada tabel berikut:

Tabel 1. Case Processing Summary

\begin{tabular}{|ll|l|l|}
\hline & $\mathrm{N}$ & $\%$ \\
\hline Cases & Valid & 30 & 100.0 \\
& Excluded(a) & 0 & .0 \\
& Total & 30 & 100.0 \\
\hline
\end{tabular}

a Listwise deletion based on all variables in the procedure.

Sumber: Diolah dari hasil jawaban responnden dengan SPSS Versi 17,0

Dari tabel di atas, diketahui bahwa skor jawaban 30 responden $100 \%$ sudah valid. Hasil uji reliabilitas secara simultan mengenai sikap mahasiswa disajikan pada tabel berikut:

Tabel 2. Reliability Statistics

\begin{tabular}{|l|l|}
\hline Cronbach's Alpha & N of Items \\
\hline 0,915 & 30 \\
\hline
\end{tabular}

Sumber: Diolah dari hasil jawaban responnden dengan SPSS Versi 17,0

Dari tabel di atas, terlihat bahwa seluruh instrumen pengukuran variabel sikap, norma subjektif dan kontrol perilaku yang dirasakan mahasiswa sudah reliabel, karena nilai cronbach's alpha sebesar 0,915 >0,50. Selanjutnya disajikan hasil uji validitas dan reliabilitas secara parsial seperti pada tabel berikut:

Tabel 3. Item-Total Statistics

\begin{tabular}{|l|l|l|l|l|}
\hline Variabel & Correlation & Keterangan & $\begin{array}{l}\text { Cronbach's } \\
\text { Alpha if } \\
\text { Item }\end{array}$ & Keterangan \\
\hline Sikap Mahasiswa (Ab) & \multicolumn{5}{|l|}{} \\
\hline Kecanggihan teknologi (b1) & 0,345 & Valid & 0,914 & Reliabel \\
Garansi (b2) & 0,369 & Valid & 0,914 & Reliabel \\
Purna jual (b3) & 0,535 & Valid & 0,912 & Reliabel \\
Kemudahan tempat service (b4) & 0,315 & Valid & 0,915 & Reliabel \\
Kemudahan sparepart (b5) & 0,344 & Valid & 0,915 & Reliabel \\
Kecanggihan teknologi (e1) & 0,649 & Valid & 0,910 & Reliabel \\
Garansi (e2) & 0,354 & Valid & 0,914 & Reliabel \\
Purna jual (e3) & 0,440 & Valid & 0,913 & Reliabel \\
Kemudahan tempat service (e4) & 0,405 & Valid & 0,914 & Reliabel \\
Kemudahan sparepart (e5) & 0,397 & Valid & 0,914 & Reliabel \\
\hline Norma Subjektif (SN) & 0,677 \\
\hline Keluarga (Nb1) & Valid \\
\hline
\end{tabular}


Volume 17 Nomor 2

\begin{tabular}{|c|c|c|c|c|}
\hline Variabel & Correlation & Keterangan & \begin{tabular}{|l|} 
Cronbach's \\
Alpha if \\
Item
\end{tabular} & Keterangan \\
\hline Teman dekat (Nb2) & 0,357 & Valid & 0,914 & Reliabel \\
\hline Rekan mahasiswa (Nb3) & 0,600 & Valid & 0,910 & Reliabel \\
\hline Tetangga $(\mathrm{Nb} 4)$ & 0,377 & Valid & 0,914 & Reliabel \\
\hline Tenaga pemasar (Nb5) & 0,473 & Valid & 0,913 & Reliabel \\
\hline Keluarga (Mc1) & 0,607 & Valid & 0,910 & Reliabel \\
\hline Teman dekat (Mc2) & 0,492 & Valid & 0,912 & Reliabel \\
\hline Rekan mahasiswa (Mc3) & 0,620 & Valid & 0,910 & Reliabel \\
\hline Tetangga (Mc4) & 0,436 & Valid & 0,913 & Reliabel \\
\hline Tenaga pemasar (Mc5) & 0,581 & Valid & 0,911 & Reliabel \\
\hline \multicolumn{5}{|c|}{ Kontrol Perilaku yang Dirasakan (PC) } \\
\hline Kecanggihan teknologi (P1) & 0,614 & Valid & 0,910 & Reliabel \\
\hline Garansi (P2) & 0,447 & Valid & 0,913 & Reliabel \\
\hline Purna jual (P3) & 0,612 & Valid & 0,910 & Reliabel \\
\hline Kemudahan tempat service (P4) & 0,743 & Valid & 0,908 & Reliabel \\
\hline Kemudahan sparepart (P5) & 0,542 & Valid & 0,911 & Reliabel \\
\hline Kecanggihan teknologi (C1) & 0,498 & Valid & 0,912 & Reliabel \\
\hline Garansi (C2) & 0,426 & Valid & 0,913 & Reliabel \\
\hline Purna jual (C3) & 0,604 & Valid & 0,910 & Reliabel \\
\hline Kemudahan tempat service (C4) & 0,470 & Valid & 0,913 & Reliabel \\
\hline Kemudahan sparepart (C5) & 0,451 & Valid & 0,913 & Reliabel \\
\hline
\end{tabular}

Sumber: Diolah dari hasil jawaban responnden dengan SPSS Versi 17,0

Dari tabel tersebut, terlihat bahwa setiap atribut pengukuran variabel sikap, norma subjektif dan kontrol perilaku yang dirasakan mahasiswa, secara rata-rata sudah valid, karena nilai $r_{\text {hitung }}>0,30$. Berdasarkan tabel tersebut, diketahui bahwa seluruh variabel penelitian sudah reliabel, karena nilai cronbach's alpha if item lebih besar 0,50.

\section{B. Sikap Mahasiswa}

Berdasarkan jawaban responden, dapat dihitung jumlah dan persentase jawaban responden mengenai sikap mahasiswa, seperti tabel berikut :

Tabel 4. Jumlah dan Persentase Jawaban Responden Mengenai Sikap Mahasiswa

\begin{tabular}{|l|l|l|l|l|l|l|l|l|}
\hline \multirow{2}{*}{ Atribut } & \multicolumn{9}{|l|}{ Jumlah } & \multicolumn{2}{l|}{ Persentase } \\
\cline { 2 - 9 } & SS & S & TS & STS & SS & S & TS & STS \\
\hline Keyakinan (bi) & & & & & & & & \\
b1 & 13 & 37 & 45 & 1 & $14 \%$ & $39 \%$ & $47 \%$ & $1 \%$ \\
b2 & 14 & 68 & 11 & 3 & $15 \%$ & $71 \%$ & $11 \%$ & $3 \%$ \\
b3 & 15 & 21 & 59 & 1 & $16 \%$ & $22 \%$ & $61 \%$ & $1 \%$ \\
b4 & 10 & 47 & 37 & 2 & $10 \%$ & $49 \%$ & $39 \%$ & $2 \%$ \\
b5 & 14 & 44 & 37 & 1 & $15 \%$ & $46 \%$ & $39 \%$ & $1 \%$ \\
\hline Evaluasi akibat (ei) & & & & & & & & \\
e1 & 13 & 66 & 16 & 1 & $14 \%$ & $69 \%$ & $17 \%$ & $1 \%$ \\
e2 & 18 & 64 & 13 & 1 & $19 \%$ & $67 \%$ & $14 \%$ & $1 \%$ \\
e3 & 10 & 53 & 32 & 1 & $10 \%$ & $55 \%$ & $33 \%$ & $1 \%$ \\
e4 & 9 & 65 & 18 & 4 & $9 \%$ & $68 \%$ & $19 \%$ & $4 \%$ \\
e5 & 12 & 63 & 20 & 1 & $13 \%$ & $66 \%$ & $21 \%$ & $1 \%$ \\
\hline
\end{tabular}

Sumber: Diolah dari hasil jawaban responnden dengan SPSS Versi 17,0 
Mahasiswa yang menyatakan sangat setuju dan setuju termasuk pada kelompok setuju sebesar 50 orang (52\%); sedangkan yang menyatakan tidak setuju dan sangat tidak setuju termasuk pada kelompok tidak setuju sebesar 46 orang (48\%). Dengan demikian, mahasiswa yakin bahwa membeli laptop merek Lenovo memiliki kecanggihan teknologi yang tinggi dibandingkan dengan lain.

Mahasiswa yang menyatakan sangat setuju dan setuju termasuk pada kelompok setuju sebesar 82 orang (85\%); sedangkan yang menyatakan tidak setuju dan sangat tidak setuju termasuk pada kelompok tidak setuju sebesar 14 orang (15\%). Dengan demikian, mahasiswa yakin, jika membeli laptop merek Lenovo akan mendapatkan garansi sebagai jaminan kualitas produk.

Mahasiswa yang menyatakan sangat setuju dan setuju termasuk pada kelompok setuju sebesar 69 orang (38\%); sedangkan yang menyatakan tidak setuju dan sangat tidak setuju termasuk pada kelompok tidak setuju sebesar 60 orang (63\%). Dengan demikian, mahasiswa tidak yakin, jika membeli laptop merek Lenovo memiliki purna jual tinggi dibandingkan yang lain.

Mahasiswa yang menyatakan sangat setuju dan setuju termasuk pada kelompok setuju sebesar 57 orang (59\%); sedangkan yang menyatakan tidak setuju dan sangat tidak setuju termasuk pada kelompok tidak setuju sebesar 39 orang $(41 \%)$. Dengan demikian, mahasiswa yakin, jika membeli laptop merek Lenovo akan mendapatkan kemudahan tempat service.

Mahasiswa yang menyatakan sangat setuju dan setuju termasuk pada kelompok setuju sebesar 58 orang (60\%); sedangkan yang menyatakan tidak setuju dan sangat tidak setuju termasuk pada kelompok tidak setuju sebesar 38 orang (40\%). Dengan demikian, mahasiswa yakin, jika membeli laptop merek Lenovo akan mendapatkan kemudahan sparepart.

Mahasiswa yang menyatakan sangat setuju dan setuju termasuk pada kelompok setuju sebesar 79 orang (82\%); sedangkan yang menyatakan tidak setuju dan sangat tidak setuju termasuk pada kelompok tidak setuju sebesar 17 orang (18\%). Dengan demikian, mahasiswa menilai bahwa jika membeli laptop merek Lenovo akan memiliki kecanggihan teknologi yang tinggi.

Mahasiswa yang menyatakan sangat setuju dan setuju termasuk pada kelompok setuju sebesar 82 orang (85\%); sedangkan yang menyatakan tidak setuju dan sangat tidak setuju termasuk pada kelompok tidak setuju sebesar 14 orang (15\%). Dengan demikian, mahasiswa menilai bahwa jika membeli laptop merek Lenovo akan mendapatkan garansi.

Mahasiswa yang menyatakan sangat setuju dan setuju termasuk pada kelompok setuju sebesar 63 orang (66\%); sedangkan yang menyatakan tidak setuju dan sangat tidak setuju termasuk pada kelompok tidak setuju sebesar 33 orang (34\%). Dengan demikian, mahasiswa menilai bahwa jika membeli laptop merek Lenovo akan memperoleh purna jual tinggi dibandingkan yang lain.

Mahasiswa yang menyatakan sangat setuju dan setuju termasuk pada kelompok setuju sebesar 74 orang (77\%); sedangkan yang menyatakan tidak setuju dan sangat tidak setuju termasuk pada kelompok tidak setuju sebesar 22 orang (23\%). Dengan demikian, mahasiswa menilai bahwa jika membeli laptop merek Lenovo akan memperoleh kemudahan tempat service.

Mahasiswa yang menyatakan sangat setuju dan setuju termasuk pada kelompok setuju sebesar 75 orang (78\%); sedangkan yang menyatakan tidak setuju dan sangat tidak setuju termasuk kelompok tidak setuju sebesar 21 orang (22\%). Dengan demikian, mahasiswa menilai bahwa jika membeli laptop merek Lenovo akan memperoleh kemudahan sparepart.

\section{Norma Subjektif}

Berdasarkan jawaban responden, dapat dihitung jumlah dan persentase jawaban responden mengenai norma subjektif pada, seperti pada tabel berikut :. 
Volume 17 Nomor 2

Tabel 5. Jumlah dan Persentase Jawaban Responden Mengenai Norma Subjektif

\begin{tabular}{|l|l|l|l|l|l|l|l|l|}
\hline \multirow{2}{*}{ Atribut } & \multicolumn{2}{l}{ Jumlah } & \multicolumn{2}{l|}{ Persentase } \\
\cline { 2 - 9 } & SS & S & TS & STS & SS & S & TS & STS \\
\hline Keyakinan Normatif (NBj) & & & & & & & & \\
Nb1 & 9 & 47 & 37 & 3 & $9 \%$ & $49 \%$ & $39 \%$ & $3 \%$ \\
Nb2 & 13 & 46 & 37 & 0 & $14 \%$ & $48 \%$ & $39 \%$ & $0 \%$ \\
Nb3 & 16 & 52 & 27 & 1 & $17 \%$ & $54 \%$ & $28 \%$ & $1 \%$ \\
Nb4 & 4 & 39 & 41 & 12 & $4 \%$ & $41 \%$ & $43 \%$ & $13 \%$ \\
Nb5 & 8 & 51 & 32 & 5 & $8 \%$ & $53 \%$ & $33 \%$ & $5 \%$ \\
\hline Motivasi (MCj) & & & & & & & & \\
MC1 & 15 & 47 & 31 & 3 & $16 \%$ & $49 \%$ & $32 \%$ & $3 \%$ \\
MC2 & 5 & 52 & 36 & 3 & $5 \%$ & $54 \%$ & $38 \%$ & $3 \%$ \\
MC3 & 10 & 51 & 34 & 1 & $10 \%$ & $53 \%$ & $35 \%$ & $1 \%$ \\
MC4 & 4 & 28 & 56 & 8 & $4 \%$ & $29 \%$ & $58 \%$ & $8 \%$ \\
MC5 & 8 & 36 & 47 & 5 & $8 \%$ & $38 \%$ & $49 \%$ & $5 \%$ \\
\hline
\end{tabular}

Sumber: Diolah dari hasil jawaban responnden dengan SPSS Versi 17,0

Mahasiswa yang menyatakan sangat setuju dan setuju termasuk kelompok setuju sebanyak 56 orang (58\%); sedangkan yang menyatakan tidak setuju dan sangat tidak setuju termasuk kelompok tidak setuju sebanyak 40 orang (42\%). Dengan demikian, jika responden membeli laptop merek Lenovo, lebih yakin yang disarankan keluarga.

Mahasiswa yang menyatakan sangat setuju dan setuju termasuk kelompok setuju sebanyak 59 orang (61\%); sedangkan yang menyatakan tidak setuju dan sangat tidak setuju termasuk kelompok tidak setuju sebanyak 37 orang (39\%). Dengan demikian, jika responden membeli laptop merek Lenovo, lebih yakin yang disarankan teman dekat.

Mahasiswa yang menyatakan sangat setuju dan setuju termasuk kelompok setuju sebanyak 68 orang (71\%); sedangkan yang menyatakan tidak setuju dan sangat tidak setuju termasuk kelompok tidak setuju sebanyak 28 orang (29\%). Dengan demikian, jika responden membeli laptop merek Lenovo, lebih yakin yang disarankan rekan mahasiswa.

Mahasiswa yang menyatakan sangat setuju dan setuju termasuk kelompok setuju 43 orang $(45 \%)$; sedangkan yang menyatakan tidak setuju dan sangat tidak setuju termasuk kelompok tidak setuju 53 orang (55\%). Dengan demikian, jika responden membeli laptop merek Lenovo, tidak yakin yang disarankan tetangga.

Mahasiswa yang menyatakan sangat setuju dan setuju termasuk kelompok setuju sebanyak 59 orang (61\%); sedangkan yang menyatakan tidak setuju dan sangat tidak setuju termasuk kelompok tidak setuju sebanyak 37 orang (39\%). Dengan demikian, jika responden membeli laptop merek Lenovo, lebih yakin yang disarankan tenaga pemasar.

Mahasiswa yang menyatakan sangat setuju dan setuju termasuk kelompok setuju sebanyak 62 orang (65\%); sedangkan yang menyatakan tidak setuju dan sangat tidak setuju termasuk kelompok tidak setuju sebanyak 34 orang $(35 \%)$. Dengan demikian, jika responden membeli laptop merek Lenovo menuruti yang disarankan keluarga.

Mahasiswa yang menyatakan sangat setuju dan setuju termasuk kelompok setuju sebanyak 57 orang (59\%); sedangkan yang menyatakan tidak setuju dan sangat tidak setuju termasuk kelompok tidak setuju sebanyak 39 orang (41\%). Dengan demikian, jika responden membeli laptop merek Lenovo menuruti yang disarankan teman dekat.

Mahasiswa yang menyatakan sangat setuju dan setuju termasuk kelompok setuju sebanyak 61 orang (64\%); sedangkan yang menyatakan tidak setuju dan sangat tidak setuju termasuk kelompok tidak setuju sebanyak 35 orang (36\%). Dengan demikian, jika responden membeli laptop merek Lenovo menuruti yang disarankan rekan mahasiswa. 
Mahasiswa yang menyatakan sangat setuju dan setuju termasuk kelompok setuju sebanyak 32 orang (33\%); sedangkan yang menyatakan tidak setuju dan sangat tidak setuju termasuk kelompok tidak setuju sebanyak 64 orang (67\%). Dengan demikian, jika responden membeli laptop merek Lenovo tidak menuruti yang disarankan tetangga.

Mahasiswa yang menyatakan sangat setuju dan setuju termasuk kelompok setuju sebanyak 44 orang (46\%); sedangkan yang menyatakan tidak setuju dan sangat tidak setuju termasuk kelompok tidak setuju sebanyak 52 orang (54\%). Dengan demikian, jika responden membeli laptop merek Lenovo tidak menuruti yang disarankan tenaga pemasar.

\section{Kontrol Perilaku yang Dirasakan}

Berdasarkan jawaban responden, dapat dihitung jumlah dan persentase jawaban responden mengenai kontrol perilaku yang dirasakan mahasiswa, seperti pada tabel berikut:

Tabel 6. Jumlah dan Persentase Jawaban Responden Variabel Kontrol Perilaku yang Dirasakan

\begin{tabular}{|c|c|c|c|c|c|c|c|c|}
\hline \multirow{2}{*}{ Atribut } & \multicolumn{4}{|c|}{ Jumlah DI, } & \multicolumn{4}{|c|}{ Persentase } \\
\hline & SS & $\mathrm{S}$ & TS & 5TS & SS & S & TS & STS \\
\hline \multicolumn{9}{|c|}{$\begin{array}{l}\text { Keyakinan kontrol yang } \\
\text { dirasakan }(\mathrm{Pi})\end{array}$} \\
\hline P1 & 12 & 50 & 32 & 2 & $13 \%$ & $52 \%$ & $33 \%$ & $2 \%$ \\
\hline P2 & 14 & 60 & 22 & 0 & $15 \%$ & $63 \%$ & $23 \%$ & $0 \%$ \\
\hline P3 & 14 & 40 & 39 & 3 & $15 \%$ & $42 \%$ & $41 \%$ & $3 \%$ \\
\hline P4 & 11 & 51 & 32 & 2 & $11 \%$ & $53 \%$ & $33 \%$ & $2 \%$ \\
\hline P5 & 10 & 51 & 34 & 1 & $10 \%$ & $53 \%$ & $35 \%$ & $1 \%$ \\
\hline \multicolumn{9}{|c|}{ Kemudahan yang dirasakan $(\mathrm{Ci})$} \\
\hline $\mathrm{C} 1$ & 15 & 64 & 16 & 1 & $16 \%$ & $67 \%$ & $17 \%$ & $1 \%$ \\
\hline C2 & 14 & 55 & 26 & 1 & $15 \%$ & $57 \%$ & $27 \%$ & $1 \%$ \\
\hline C3 & 8 & 45 & 41 & 2 & $8 \%$ & $47 \%$ & $43 \%$ & $2 \%$ \\
\hline C4 & 12 & 55 & 26 & 3 & $13 \%$ & $57 \%$ & $27 \%$ & $3 \%$ \\
\hline C5 & 11 & 47 & 37 & 10 & $11 \%$ & $49 \%$ & $39 \%$ & $1 \%$ \\
\hline
\end{tabular}

Sumber: Diolah dari hasil jawaban responnden dengan SPSS Versi 17,0

Mahasiswa yang menyatakan sangat setuju dan setuju termasuk kelompok setuju sebanyak 62 orang (65\%); sedangkan yang menyatakan tidak setuju dan sangat tidak setuju termasuk kelompok tidak setuju sebanyak 34 orang (35\%). Dengan demikian, mahasiswa yakin bahwa jika membeli laptop merek Lenovo kecanggihan teknologinya sesuai yang diharapkan.

Mahasiswa yang menyatakan sangat setuju dan setuju termasuk kelompok setuju sebanyak 74 orang (77\%); sedangkan yang menyatakan tidak setuju dan sangat tidak setuju termasuk kelompok tidak setuju sebanyak 22 orang (23\%). Dengan demikian, mahasiswa yakin bahwa jika membeli laptop merek Lenovo memperoleh garansi sesuai yang diharapkan.

Mahasiswa yang menyatakan sangat setuju dan setuju termasuk kelompok setuju sebanyak 54 orang (55\%); sedangkan yang menyatakan tidak setuju dan sangat tidak setuju termasuk kelompok tidak setuju sebanyak 42 orang (44\%). Dengan demikian, mahasiswa yakin bahwa jika membeli laptop merek Lenovo memiliki purna jual yang tinggi sesuai diharapkan.

Mahasiswa yang menyatakan sangat setuju dan setuju termasuk kelompok setuju sebanyak 62 orang (65\%); sedangkan yang menyatakan tidak setuju dan sangat tidak setuju termasuk kelompok tidak setuju sebanyak 34 orang (35\%). Dengan demikian, mahasiswa yakin bahwa jika membeli laptop merek Lenovo akan memberikan kemudahan tempat service sesuai yang diharapkan. 
Mahasiswa yang menyatakan sangat setuju dan setuju termasuk kelompok setuju sebanyak 61 orang (64\%); sedangkan yang menyatakan tidak setuju dan sangat tidak setuju termasuk kelompok tidak setuju sebanyak 35 orang (36\%). Dengan demikian, mahasiswa yakin bahwa jika membeli laptop merek Lenovo akan memberikan kemudahan sparepart sesuai yang diharapkan.

Mahasiswa yang menyatakan sangat setuju dan setuju termasuk kelompok setuju sebanyak 79 orang (82\%); sedangkan yang menyatakan tidak setuju dan sangat tidak setuju termasuk kelompok tidak setuju sebanyak 17 orang $(18 \%)$. Dengan demikian, mahasiswa yakin bahwa jika membeli laptop merek Lenovo kecanggihan teknologi akan memberikan kemudahan dalam setiap penyelesaian tugas-tugas.

Mahasiswa yang menyatakan sangat setuju dan setuju termasuk kelompok setuju sebanyak 69 orang (72\%); sedangkan yang menyatakan tidak setuju dan sangat tidak setuju termasuk kelompok tidak setuju sebanyak 27 orang (28\%). Dengan demikian, mahasiswa yakin bahwa jika membeli laptop merek Lenovo garansinya dapat memberikan kemudahan memperbaiki ketika rusak.

Mahasiswa yang menyatakan sangat setuju dan setuju termasuk kelompok setuju sebanyak 53 orang (55\%); sedangkan yang menyatakan tidak setuju dan sangat tidak setuju termasuk kelompok tidak setuju sebanyak 43 orang $(45 \%)$. Dengan demikian, mahasiswa ingin membeli laptop merek Lenovo purna jualnya tinggi, sehingga memudahkan untuk mendapatkan sebagian dari harga jualnya.

Mahasiswa yang menyatakan sangat setuju dan setuju termasuk kelompok setuju sebanyak 67 orang (70\%); sedangkan yang menyatakan tidak setuju dan sangat tidak setuju termasuk kelompok tidak setuju sebanyak 29 orang (30\%). Dengan demikian, mahasiswa ingin membeli laptop merek Lenovo karena kemudahan tempat service.

Mahasiswa yang menyatakan sangat setuju dan setuju termasuk kelompok setuju sebanyak 58 orang (60\%); sedangkan yang menyatakan tidak setuju dan sangat tidak setuju termasuk kelompok tidak setuju sebanyak 38 orang (40\%). Dengan demikian, mahasiswa ingin membeli laptop merek Lenovo karena kemudahan sparepart.

\section{E. PEMBAHASAN}

\section{Analisis Sikap}

1. Keyakinan akan perilaku (bi)

Nilai atribut dari variabel keyakinan disajikan pada tabel berikut:

Tabel 7. Nilai Atribut dari Variabel Keyakinan

\begin{tabular}{|l|l|l|l|l|l|l|}
\hline \multirow{2}{*}{ Atribut } & SS & S & TS & STS & \multirow{2}{*}{ Rata-rata tertimbang } & Penilaian \\
\cline { 2 - 5 } & $(2)$ & $(1)$ & $(-1)$ & $(-2)$ & & Positif \\
\hline $\mathrm{b}_{1}$ & 13 & 37 & 45 & 1 & 0,167 & Positif \\
$\mathrm{b}_{2}$ & 14 & 68 & 11 & 3 & 0,823 & Negatif \\
$\mathrm{b}_{3}$ & 15 & 21 & 59 & 1 & $-0,104$ & Positif \\
$\mathrm{b}_{4}$ & 10 & 47 & 37 & 2 & 0,271 & Positif \\
$\mathrm{b}_{5}$ & 14 & 44 & 37 & 1 & 0,344 & - \\
\hline Jumlah & & & & & 1,500 & Positif \\
Rata-rata & & & & & 0,300 & \\
\hline
\end{tabular}

Sumber: Diolah dari hasil jawaban responnden dengan SPSS Versi 17,0

Berdasarkan tabel di atas, menunjukkan keyakinan mahasiswa Fakultas Ekonomi Unika St. Thomas Sumatera Utara mengenai atribut laptop merek Lenovo. Rata-rata skor jawaban responden dihitung dengan cara membagi antara jumlah skor dengan jumlah sub variabel. Rata-rata tertimbang dihitung dengan cara mengalikan antara total jawaban 
responden untuk tiap alternatif dengan alternatif pilihan jawaban. Misalnya rata-rata tertimbang skor jawaban responden mengenai kecanggihan teknologi $\left(b_{1}\right)$ adalah:

$$
\text { Rata }- \text { rata tertimbang }=\frac{(13 \times 2)+(37 \times 1)+(45 \times-1)+(1 \times-2)}{96}=0,167 \ldots \ldots \ldots \ldots . .14
$$

Berdasarkan tabel 4.7, terlihat bahwa rata-rata mahasiswa mempunyai keyakinan yang positif jika membeli laptop merek Lenovo.

2. Evaluasi (ei)

Nilai atribut dari variabel evaluasi mahasiswa disajikan pada tabel berikut:

Tabel 8. Nilai Atribut dari Variabel Evaluasi

\begin{tabular}{|l|l|l|l|l|l|l|}
\hline \multirow{2}{*}{ Atribut } & SP & $\mathbf{P}$ & $\mathbf{N}$ & SN & Rata-rata & \multirow{2}{*}{ Penilaian } \\
\cline { 2 - 6 } & $(2)$ & $(1)$ & $(-1)$ & $(-2)$ & tertimbang & \\
\hline $\mathrm{e}_{1}$ & 13 & 66 & 16 & 1 & 0,771 & Positif \\
$\mathrm{e}_{2}$ & 18 & 64 & 13 & 1 & 0,885 & Positif \\
$\mathrm{e}_{3}$ & 10 & 53 & 32 & 1 & 0,406 & Positif \\
$\mathrm{e}_{4}$ & 9 & 65 & 18 & 4 & 0,594 & Positif \\
$\mathrm{e}_{5}$ & 12 & 63 & 20 & 1 & 0,677 & Positif \\
\hline Jumlah & & & & & 3,333 & - \\
Rata-rata & & & & & 0,667 & Positif \\
\hline
\end{tabular}

Sumber: Diolah dari hasil jawaban responnden dengan SPSS Versi 17,0

Berdasarkan tabel tersebut, berarti rata-rata mahasiswa memberikan penilaian yang positif jika membeli laptop merek Lenovo.

3. Nilai sikap $(\mathrm{Ab})$

Sikap mahasiswa menunjukkan sikap responden terhadap perilaku untuk membeli laptop merek lenovo. Nilai atribut dari variabel sikap mahasiswa disajikan pada tabel berikut:

Tabel 9. Nilai Sikap

\begin{tabular}{|c|c|c|c|c|}
\hline $\begin{array}{l}\text { Sub } \\
\text { variabel }\end{array}$ & Keyakinan (bi) & $\begin{array}{l}\text { Evaluasi } \\
\text { (ei) }\end{array}$ & $\begin{array}{l}\text { Sikap } \\
\text { mahasiswa } \\
\mathrm{Ab}=(\mathrm{bi} \times \mathrm{ei})\end{array}$ & Penilaian \\
\hline$A b_{1}$ & 0,167 & 0,771 & 0,128 & Positif \\
\hline $\mathrm{Ab}_{2}$ & 0,823 & 0,885 & 0,729 & Positif \\
\hline $\mathrm{Ab}_{3}$ & $-0,104$ & 0,406 & $-0,042$ & Negatif \\
\hline $\mathrm{Ab}_{4}$ & 0,271 & 0,594 & 0,161 & Positif \\
\hline $\mathrm{Ab}_{5}$ & 0,344 & 0,677 & 0,233 & Positif \\
\hline Jumlah & 1,500 & 3,333 & 1,208 & - \\
\hline Rata-rata & 0,300 & 0,667 & 0,242 & Positif \\
\hline
\end{tabular}

Sumber: Diolah dari hasil jawaban responnden dengan SPSS Versi 17,0

Tabel di atas menunjukkan keterangan mengenai kuat tidaknya pengaruh sikap mahasiswa $(\mathrm{Ab})$ dengan mengalikan antara nilai keyakinan (bi) dengan evaluasi $\left(\mathrm{e}_{\mathrm{i}}\right)$. Dari tabel tersebut terlihat bahwa mahasiswa bersikap positif atas atribut laptop merek lenovo. Untuk mengetahui sikap mahasiswa 1,208 (tabel 5.9) berada pada skala penilaian yang mana, dihitung dulu skor maksimum untuk sikap mahasiswa, seperti ditampilkan pada tabel berikut:

Tabel 10 Rentang Nilai Sikap Maksimum - Minimum

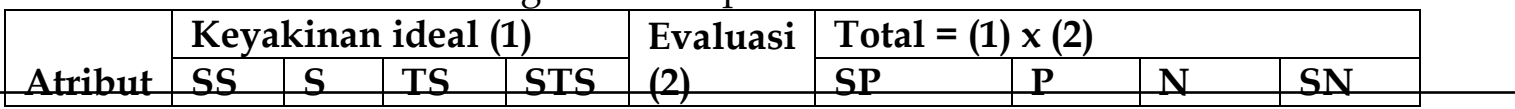


Volume 17 Nomor 2

\begin{tabular}{|l|l|l|l|l|l|l|l|l|l|}
1 & 2 & 1 & -1 & -2 & 0,771 & 1,54 & 0,77 & $-0,77$ & $-1,54$ \\
2 & 2 & 1 & -1 & -2 & 0,885 & 1,77 & 0,89 & $-0,89$ & $-1,77$ \\
3 & 2 & 1 & -1 & -2 & 0,406 & 0,81 & 0,41 & $-0,41$ & $-0,81$ \\
4 & 2 & 1 & -1 & -2 & 0,594 & 1,19 & 0,59 & $-0,59$ & $-1,19$ \\
5 & 2 & 1 & -1 & -2 & 0,677 & 1,35 & 0,68 & $-0,68$ & $-1,35$ \\
\hline Jumlah
\end{tabular}

Sumber: Hasil olahan penulis

Oleh karena rentang skor +2 sebagai sangat positif dan -2 sebagai sangat negatif, maka rentang nilai sikap maksimum adalah 6,67 dan minimum -6,67. Berdasarkan skala tersebut, maka nilai sikap mahasiswa sebesar 1,208 berada pada kategori positif.

\section{Analisis Norma Subjektif}

1. Keyakinan normatif (NBj)

Nilai atribut variabel keyakinan normatif disajikan pada tabel berikut:

Tabel 11Nilai Atribut Variabel Keyakinan Normatif

\begin{tabular}{|c|c|c|c|c|c|c|}
\hline \multirow[b]{2}{*}{ Atribut } & SS & S & TS & STS & \multirow{2}{*}{$\begin{array}{c}\text { Rata-rata } \\
\text { Tertimbang }\end{array}$} & \multirow{2}{*}{ Penilaian } \\
\hline & (2) & (1) & $(-1)$ & $(-2)$ & & \\
\hline $\mathrm{NB}_{1}$ & 9 & 47 & 37 & 3 & 0,229 & Positif \\
\hline $\mathrm{NB}_{2}$ & 13 & 46 & 37 & 0 & 0,365 & Positif \\
\hline $\mathrm{NB}_{3}$ & 16 & 52 & 27 & 1 & 0,573 & Positif \\
\hline $\mathrm{NB}_{4}$ & $4 C$ & 39 & 41 & 12 & $-0,188$ & Negatif \\
\hline $\mathrm{NB}_{5}$ & 8 & 51 & 32 & 5 & 0,260 & Positif \\
\hline $\begin{array}{l}\text { Jumlah } \\
\text { Rata-rata }\end{array}$ & & & & & $\begin{array}{l}1,240 \\
0,248\end{array}$ & \\
\hline
\end{tabular}

Sumber: Hasil olahan penulis

Dari tabel di atas, ditunjukkan bahwa keyakinan yang diterima mahasiswa dari kelompok preferen secara rata-rata memberikan pengaruh positif.

2. Motivasi (MCj)

Nilai atribut variabel motivasi disajikan pada tabel berikut:

Tabel 12. Nilai Atribut Variabel Motivasi

\begin{tabular}{|l|l|l|l|l|l|l|}
\hline \multirow{2}{*}{ Atribut } & SS & S & TS & STS & Rata-rata & Penilaian \\
\cline { 2 - 6 } & $\mathbf{( 2 )}$ & $(\mathbf{1})$ & $\mathbf{( - 1 )}$ & $\mathbf{( - 2 )}$ & Tertimbang & \\
\hline $\mathrm{MC}_{1}$ & 5 & 7 & 1 & &, 417 & Positif \\
$\mathrm{MC}_{2}$ & 0 & 2 & 6 & &, 208 & Positif \\
$\mathrm{MC}_{3}$ & 1 & 4 & &, 365 & Positif \\
$\mathrm{MC}_{4}$ & & 8 & 6 & & 0,375 & Negatif \\
$\mathrm{MC}_{5}$ & 6 & 7 & & 0,052 & Negatif \\
\hline Jumlah & & & & &, 563 & Positif \\
\hline Rata-rata & & & & &, 113 & \\
\hline
\end{tabular}

Sumber: Hasil olahan penulis

Berdasarkan tabel 12, terlihat bahwa motivasi mahasiswa dari kelompok preferen secara rata-rata memberikan pengaruh positif. 
Volume 17 Nomor 2

3. Norma Subjektif (SN).

Nilai atribut dari variabel norma subjektif disajikan pada tabel berikut:

Tabel 13. Nilai Norma Subjektif

\begin{tabular}{|l|l|l|l|l|}
\hline $\begin{array}{l}\text { Sub } \\
\text { variabel }\end{array}$ & $\begin{array}{l}\text { Keyakinan } \\
\text { normatif } \mathbf{( N B j )}\end{array}$ & $\begin{array}{l}\text { Motivasi } \\
\mathbf{( M C j})\end{array}$ & $\begin{array}{l}\text { Norma subjektif } \\
\text { SN= (NBj } \mathbf{x} \text { MCj) }\end{array}$ & Penilaian \\
\hline $\mathrm{SN}_{1}$ & 0,229 & 0,417 & 0,095 & Positif \\
$\mathrm{SN}_{2}$ & 0,365 & 0,208 & 0,076 & Positif \\
$\mathrm{SN}_{3}$ & 0,573 & 0,365 & 0,209 & Positif \\
$\mathrm{SN}_{4}$ & $-0,188$ & $-0,375$ & 0,070 & Positif \\
$\mathrm{SN}_{5}$ & 0,260 & $-0,052$ & $-0,014$ & Negatif \\
\hline Jumlah & 1,240 & 0,563 & 0,437 & - \\
Rata-rata & 0,248 & 0,113 & 0,087 & Positif \\
\hline
\end{tabular}

Sumber: Hasil olahan penulis

Total nilai norma subjektif diperoleh dengan mengalikan antara keyakinan normatif $(\mathrm{NBj})$ dengan variabel motivasi $(\mathrm{MCj})$. Pengaruh kelompok preferen bagi mahasiswa untuk membeli laptop merek lenovo secara rata-rata adalah positif.

\section{Analisis Kontrol Perilaku yang Dirasakan}

1. Keyakinan kontrol yang dirasakan (Pi).

Nilai atribut variabel keyakinan kontrol yang dirasakan, sebagai berikut:

Tabel 14. Nilai Atribut Variabel Keyakinan Kontrol yang Dirasakan

\begin{tabular}{|c|c|c|c|c|c|c|}
\hline \multirow{2}{*}{ Atribut } & SS & S & TS & STS & Rata-rata & \multirow{2}{*}{ Penilaian } \\
\hline & (2) & (1) & $(-1)$ & $(-2)$ & Tertimbang & \\
\hline$P_{1}$ & 12 & 50 & 32 & 2 & 0,396 & Positif \\
\hline $\mathrm{P}_{2}$ & 14 & 60 & 22 & 0 & 0,688 & Positif \\
\hline $\mathrm{P}_{3}$ & 14 & 40 & 39 & 3 & 0,240 & Positif \\
\hline $\mathrm{P}_{4}$ & 11 & 51 & 32 & 2 & 0,385 & Positif \\
\hline$P_{5}$ & 10 & 51 & $34 \mathrm{~K}$ & 1 & 0,365 & Positif \\
\hline $\begin{array}{l}\text { Jumlah } \\
\text { Rata-rata }\end{array}$ & & & & & $\begin{array}{l}2,073 \\
0,415\end{array}$ & Positif \\
\hline
\end{tabular}

Sumber: Hasil olahan penulis

Dari tabel di atas, ditunjukkan bahwa keyakinan kontrol yang dirasakan mahasiswa secara rata-rata memberikan keyakinan positif.

2. Kemudahan yang dirasakan (Ci).

Nilai atribut variabel kemudahan yang dirasakan mahasiswa, disajikan pada tabel berikut:

Tabel 15. Nilai Atribut Variabel Kemudahan yang Dirasakan

\begin{tabular}{|l|l|l|l|l|l|l|}
\hline \multirow{2}{*}{ Atribut } & SS & S & TS & STS & Rata-rata & Penilaian \\
\cline { 2 - 7 } & $(\mathbf{2})$ & $(\mathbf{1})$ & $(\mathbf{- 1})$ & $\mathbf{( - 2 )}$ & Tertimbang & \\
\hline $\mathrm{C}_{1}$ & 15 & 64 & 16 & 1 & 0,792 & Positif \\
$\mathrm{C}_{2}$ & 14 & 55 & 26 & 1 & 0,573 & Positif \\
$\mathrm{C}_{3}$ & 8 & 45 & 41 & 2 & 0,167 & Positif \\
$\mathrm{C}_{4}$ & 12 & 55 & 26 & 3 & 0,490 & Positif \\
$\mathrm{C}_{5}$ & 11 & 47 & 37 & 1 & 0,313 & Positif \\
\hline Jumlah & & & & & 2,333 & Positif \\
Rata-rata & & & & & 0,467 & Pon \\
\hline
\end{tabular}


Volume 17 Nomor 2

Sumber: Hasil olahan penulis

Berdasarkan tabel di atas, terlihat bahwa kemudahan yang dirasakan mahasiswa untuk membeli laptop merek lenovo secara rata-rata adalah positif.

3. Kontrol keperilakuan yang dirasakan (PC).

Nilai atribut variabel kontrol keperilakuan yang dirasakan, seperti tabel berikut:

Tabel 16. Nilai Kontrol Keperilakuan yang Dirasakan

\begin{tabular}{|l|l|l|l|l|}
\hline Sub variabel & $\mathbf{P i}$ & $\mathbf{C i}$ & $\mathbf{P C}=\mathbf{( P i} \times \mathbf{C i})$ & Penilaian \\
\hline $\mathrm{PC}_{1}$ & 0,396 & 0,792 & 0,313 & Positif \\
$\mathrm{PC}_{2}$ & 0,688 & 0,573 & 0,394 & Positif \\
$\mathrm{PC}_{3}$ & 0,240 & 0,167 & 0,040 & Positif \\
$\mathrm{PC}_{4}$ & 0,385 & 0,490 & 0,189 & Positif \\
$\mathrm{PC}_{5}$ & 0,365 & 0,313 & 0,114 & Positif \\
\hline Jumlah & 2,073 & 2,333 & 1,050 & - \\
Rata-rata & 0,415 & 0,467 & 0,210 & Positif \\
\hline
\end{tabular}

Sumber: Hasil olahan penulis

Total nilai kontrol keperilakuan yang dirasakan diperoleh dengan mengalikan antara keyakinan yang dirasakan (Pi) dengan variabel kemudahan yang Dirasakan (Ci). Nilai kontrol keperilakuan yang dirasakan mahasiswa untuk membeli laptop merek lenovo secara rata-rata positif.

\section{Analisis Perilaku Untuk Membeli Laptop Lenovo}

Berdasarkan tabel diatas, diketahui total $b_{i}=144$, total $e_{i}=320$, total $N B j=119$, total $\mathrm{MCj}=54$, total $\mathrm{Pi}=199$ dan total $\mathrm{Ci}=224$. Dengan demikian dapat dihitung W1, W2 dan W3 sebagai berikut:

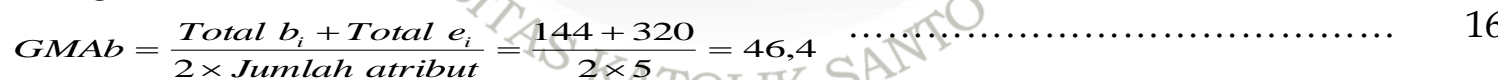

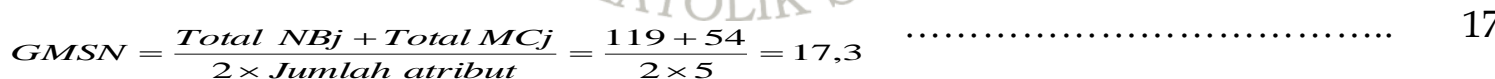

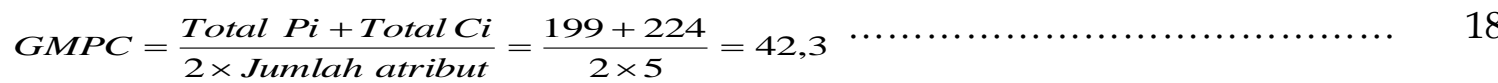

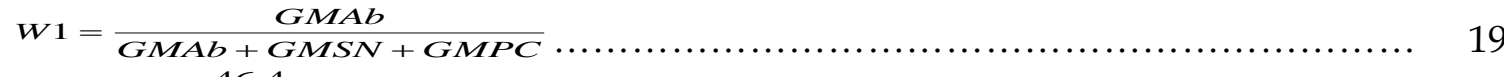

$$
\begin{aligned}
& =\frac{46,4}{46,4+17,3+42,3} \\
& =0,44 \\
& W 2=\frac{G M S N}{G M A b+G M S N+G M P C} \\
& =\frac{17,3}{46,4+17,3+42,3} \\
& =0,16 \\
& W 3=\frac{G M S N}{G M A b+G M S N+G M P C} \\
& =\frac{42,3}{46,4+17,3+42,3} \\
& =0,40
\end{aligned}
$$

Berdasarkan hasil perhitungan di atas, diperoleh persamaan perilaku mahasiswa untuk membeli laptop merek Lenovo (BI) sebagai berikut :

$$
\begin{aligned}
(\mathrm{B}=\mathrm{BI}) & =\mathrm{W} 1 \mathrm{Ab}+\mathrm{W} 2 \mathrm{SN}+\mathrm{W} 3 \mathrm{PC} \\
& =0,44 A \mathrm{~b}+0,16 \mathrm{SN}+0,40 \mathrm{PC}
\end{aligned}
$$


Dari persamaan tersebut ternyata bahwa perilaku mahasiswa FE Unika St. Thomas SU untuk membeli laptop merek lenovo lebih besar dipengaruhi oleh sikap sebesar 0,44 $(44 \%)$ dari pada kontrol keperilakuan yang dirasakan 0,40 (40\% dan norma subjektif 0,16 $(16 \%)$.

Penelitian ini dilakukan pada mahasiswa FE Unika St. Thomas SU dengan sampel penelitian 96 orang. Pembahasan variabel penelitian yang terdiri dari tiga sub variabel yakni:

1. Tabel 5.9, menunjukkan bahwa sikap mahasiswa FE Unika St. Thomas SU secara rata-rata memberikan pengaruh yang positif terhadap perilaku untuk membeli laptop merek lenovo.

2. Tabel 5.13, menunjukkan bahwa mahasiswa jika membeli laptop merek lenovo karena pengaruh kelompok preferen yang secara rata-rata memberikan motivasi yang positif.

3. Tabel 5.16, menunjukkan bahwa nilai kontrol keperilakuan yang dirasakan mahasiswa FE Unika St. Thomas SU jika ingin membeli laptop merek lenovo secara rata-rata positif.

4. Berdasarkan persamaan minat berperilaku $=\mathrm{BI}=0,44 \mathrm{Ab}+0,16 \mathrm{SN}+0,40 \mathrm{PC}$. Artinya perilaku untuk membeli laptop lenovo lebih besar dipengaruhi oleh sikap mahasiswa sebesar 0,44 (44\%) dari pada kontrol perilaku yang dirasakan 0,40 (40\%) dan norma subjektif $0,16(16 \%)$.

\section{KESIMPULAN DAN SARAN}

\section{A. Kesimpulan}

Berdasarkan hasil pembahasan yang telah dilakukan pada bab sebelumnya, dapat disimpulkan bahwa:

1. Sikap mahasiswa FE Unika St. Thomas SU secara rata-rata memberikan pengaruh yang positif terhadap perilaku untuk membeli laptop merek lenovo.

2. Mahasiswa FE Unika St. Thomas SU jika membeli laptop merek lenovo karena pengaruh kelompok preferen yang secara rata-rata memberikan motivasi yang positif.

3. Nilai kontrol keperilakuan yang dirasakan mahasiswa FE Unika St. Thomas SU jika ingin membeli laptop merek lenovo secara rata-rata positif.

4. Berdasarkan persamaan minat berperilaku $=\mathrm{BI}=0,44 \mathrm{Ab}+0,16 \mathrm{SN}+0,40 \mathrm{PC}$. Artinya, perilaku mahasiswa FE Unika St. Thomas SU untuk membeli laptop merek lenovo lebih besar dipengaruhi oleh sikap sebesar 0,44 (44\%) dari pada kontrol keperilakuan yang dirasakan 0,40 (40\% dan norma subjektif 0,16 (16\%)

\section{B. Saran}

Saran yang diberikan kepada perusahaan untuk mengatasi masalah yang dihadapi, yaitu:

1. Sebaiknya, produsen laptop merek lenovo meningkatkan atribut yang dipentingkan mahasiswa untuk memenangkan persaingan.

2. Sebaiknya, produsen laptop meningkatkan pengaruh norma subjektif dan kontrol keperilakuan yang dirasakan dengan menawarkan berbagai manfaat kepada konsumen.

\section{DAFTAR PUSTAKA}

Achmad, Zakarija, 2008. Theory of Planned Behavior, Artikel Dosen Fakultas Ekonomi UMM: zakarija.staff.umm.ac.id.

Boyd, Harper W; Walker, Orville dan Larrenche, Jean Claude. 2000. Manajemen Pemasaran: Suatu Pendekatan Strategis dengan Orientasi Global, Jilid Satu, Alih Bahasa: Iman Nurmawan, Jakarta: Penerbit Erlangga.

Bursan, Rinaldi, 2010. Implementation of Planned Behavior Theory at the Faculty of Economics Student Attitudes in Buying Laptop, Jurnal Bisnis dan Manajemen, ISSN 1411 - 9366 Volume 6 No.2, Januari 2010 
Candra, Gregorius, 2005. Strategi dan Program Pemasaran, Edisi Pertama, Cetakan Keempat, Yogyakarta: Andi.

Kotler, Philip dan Armstrong, Gary. 2004. Dasar-dasar Pemasaran. Jilid Satu, Alih Bahasa: Alexander Sindoro, Edisi Kesembilan, Jakarta: Indeks.

Kotler, Philip dan Armstrong, Gary, 2001. Prinsip-prinsip Pemasaran, Jilid 1, Alih Bahasa: Damos Sihombing, Edisi Kedelapan, Jakarta : Erlangga.

Peter, Paul J dan Olson, Jerry C. 2000. Costumer Behavior: Perilaku Konsumen dan Strategi Pemasaran. Alih Bahasa: Damos Sihombing. Jakarta: Erlangga.

Ronny, 2009. Sumber Terpercaya Sebagai Subjective Norm (Studi kasus : Pembelian Laptop oleh Komunitas Mahasiswa di Makassar), Adiwidia Edisi Desember 2009, Makasar: Universitas Atmajaya.

Simanihuruk, Peran, 2001. Jurnal Bisnis dan Manajemen, Fakultas Ekonomi Unika St. Thomas Medan.

Sugiyono, 2005. Metode Penelitian Bisnis, Cetakan Keenam, Bandung: Alfabeta.

Supranto, J., 2001. Statistik: Teori dan Aplikasi, Jilid Dua, Edisi Keenam, Cetakan Pertama, Jakarta: Erlangga.

Sutisna, 2001. Perilaku Konsumen dan Komunikasi Pemasaran, Edisi Pertama, Jakarta: Rosda.

Umar, Husein, 2001. Studi Kelayanan Bisnis: Teknik Menganalisis Kelayakan Rencana Bisnis Komprehensif, Edisi Kedua, Jakarta: Gramedia. 